University of Nebraska - Lincoln

DigitalCommons@University of Nebraska - Lincoln

$12-2007$

\title{
Molecules that Target beta-Amyloid
}

Cliff I. Stains

University of Nebraska-Lincoln, cstains2@unl.edu

Kalyani Mondal

University of Arizona, mondal.5@osu.edu

Indraneel Ghosh

University of Arizona, ghosh@email.arizona.edu

Follow this and additional works at: https://digitalcommons.unl.edu/chemistrystains

Part of the Chemistry Commons

Stains, Cliff I.; Mondal, Kalyani; and Ghosh, Indraneel, "Molecules that Target beta-Amyloid" (2007). Cliff Stains Publications. 7.

https://digitalcommons.unl.edu/chemistrystains/7

This Article is brought to you for free and open access by the Published Research - Department of Chemistry at DigitalCommons@University of Nebraska - Lincoln. It has been accepted for inclusion in Cliff Stains Publications by an authorized administrator of DigitalCommons@University of Nebraska - Lincoln. 


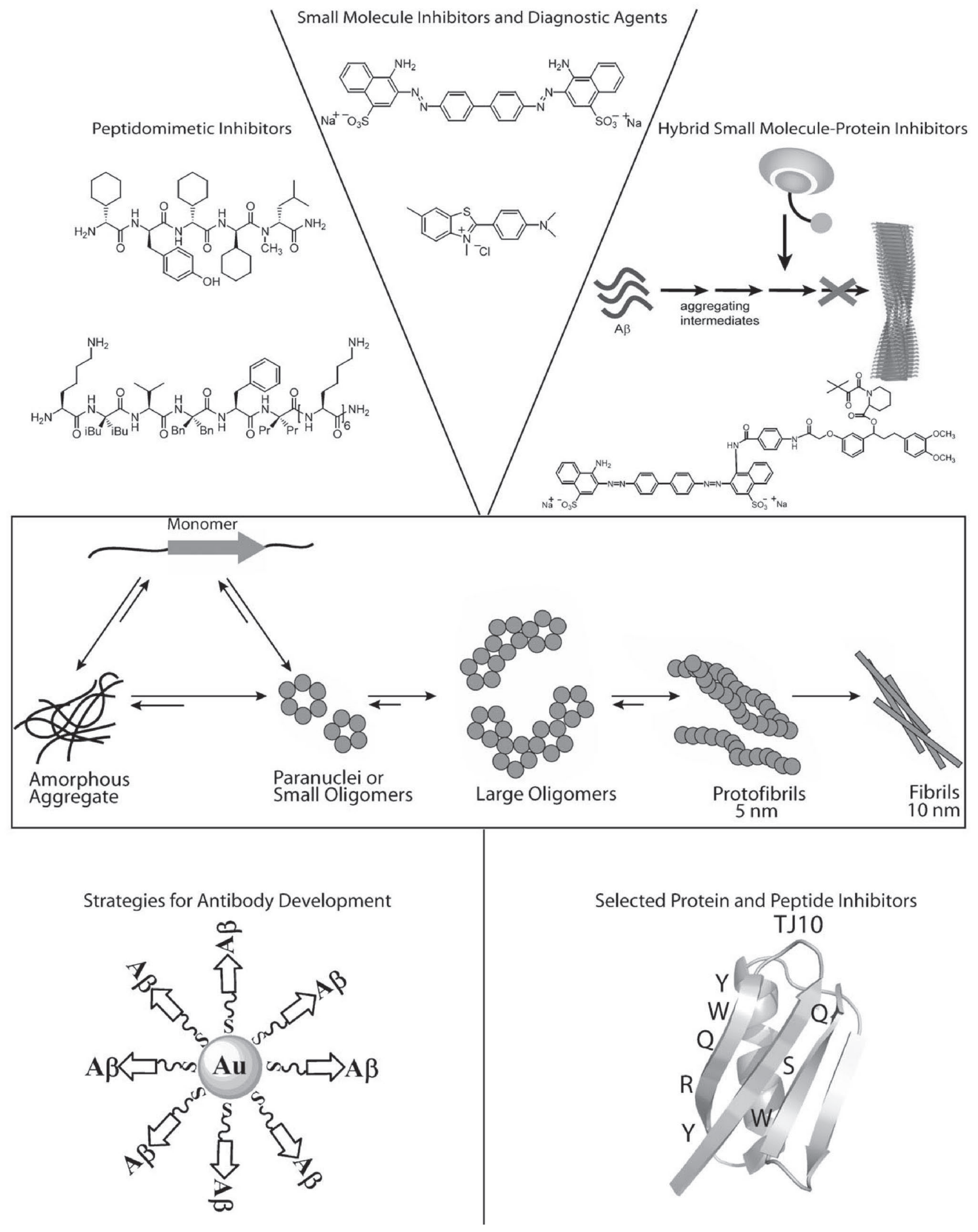




\title{
Molecules that Target beta-Amyloid
}

\author{
Cliff I. Stains, Kalyani Mondal, and Indraneel Ghosh
}

\begin{abstract}
The devastating effects of Alzheimer's and related amyloidogenic diseases have inspired the synthesis and evaluation of numerous ligands to understand the molecular mechanism of the aggregation of the beta-amyloid peptide. Our review focuses on the current knowledge in this field with respect to molecules that have been demonstrated to interact with either oligomeric or fibrillar forms of the betaamyloid peptide. We describe natural proteins, peptides, peptidomimetics, and small molecules that have been found to interfere with beta-amyloid aggregation. We also detail recent efforts in selecting molecules that target beta-amyloid isolated from antibody, protein, and peptide libraries. These new molecules will likely aid in deciphering the details of the aggregation pathway for the beta-amyloid peptide and provide reagents that may stabilize relevant oligomeric intermediates which likely have bearing on the pathophysiology of Alzheimer's disease. Moreover, the described anti-amyloid molecular toolbox will also provide an avenue for designing new diagnostic and therapeutic reagents.
\end{abstract}

Keywords: Alzheimer's, amyloid, peptides, proteins, small molecules

\section{Introduction}

The abnormal assembly of proteins is implicated in over 30 human disorders, which include Alzheimer's disease $\left(A \beta_{1-}\right.$ ${ }_{42}$ ), Parkinson's disease ( $\alpha$-synuclein), and dialysis related amyloidosis ( $\beta 2$-microglobulin). ${ }^{1-4}$ Alzheimer's disease $(A D)$ is perhaps best characterized by the extracellular deposits of the 39-42 amino acid amyloid- $\beta$ peptides $(A \beta)$ along with neurofibrillary tangles in the brains of patients. $A \beta$ peptides arise from cleavage of the extracellular portion of the transmembrane amyloid-precursor protein (APP) by $\beta$ - and $\gamma$-secretases. ${ }^{5-7}$ The elucidation of the genetic, biochemical, and biophysical origins of Alzheimer's disease (AD) remains a complex and formidable challenge. The toxicity of processed $A \beta$ peptide may include a combination of apoptosis, ${ }^{8}$ disrupted $\mathrm{Ca}^{2+}$ homeostasis, ${ }^{9}$ toxic radicals, ${ }^{10,} 11$ and complement formation. ${ }^{12}$ Over the past decade Selkoe, ${ }^{13}$ Lansbury, ${ }^{14}$ Teplow, ${ }^{15}$ Kelly, ${ }^{4}$ Dobson, ${ }^{16,17}$ and Prusiner, ${ }^{18}$ among many others have helped establish a general nucleation dependent paradigm for fibril formation (Figure 1). These ongoing experiments have also demonstrated that the rate of fibrillization and the morphology of the final fibrillar state are strongly influenced by environmental factors ( $\mathrm{pH}$, salt, temperature, agitation, etc.); chemicals (proteins, lipids, cholesterol, metals, etc.); and by the nature of the seeding agent. ${ }^{14}$ In the case of $A \beta$, evidence from both in vitro ${ }^{19,} 20$ and in vivo ${ }^{21,22}$ studies strongly suggest that soluble oligomeric $A \beta$ forms with $\beta$-sheet secondary structure are responsible for neurological toxicity (Figure 1). ${ }^{22,23}$ In this review we will briefly present current structural paradigms in $A D$ followed by a discussion of the molecular approaches towards targeting oligomers and fibrils.

The presence of amyloid plaque in the postmortem brains of patients suffering from Alzheimer's disease led to the hypothesis that these extracellular plaques were pathological to the neuronal cells. This view was further confirmed by in vi- tro experiments where $A \beta$ fibrils upon incubation with rat hippocampal cultures were found to be toxic to these neuronal cells. ${ }^{24-26}$ However, much current work with amyloidogenic proteins has led to a paradigm shift towards an oligomeric toxic species. The evidence for a toxic oligomeric intermediate rests on the following experiments: firstly, there seems to be a stronger correlation between "soluble $A \beta$ " (monomer and oligomers of $A \beta$ ) in the brain and early cognitive dysfunction than there is between the $A \beta$ deposits and clinical severity of $A D ; 27-30$ secondly, transgenic mice that overexpress APP exhibited neuronal and behavioral abnormalities before amyloid plaques were detected ${ }^{31,32}$ and thirdly, soluble oligomers of $A \beta$ were found to be toxic to cell cultures ${ }^{33,34}$ and affected hippocampal long term potentiation when injected in transgenic mice. ${ }^{21,35}$ Haass \& Selkoe have also argued that $A \beta$ aggregates present less surface area for interaction with the neurons as compared to the soluble intermediates which can easily diffuse into synaptic clefts and hence are better candidates for causing neuronal dysfunction. ${ }^{36}$ Several of these intermediates have been validated in aggregation studies of purified $A \beta$, whereas some have also been isolated and purified from cell cultures and brains of transgenic mice (Table 1).

Interestingly, studies in the similar Huntington's Disease, showed significantly less cell death when fibrils of polyglutamine oligomers of the huntingtin protein were present. ${ }^{37}, 38$ This has led many researchers to postulate that in some cases the fibrillar aggregates may protect normal cells against toxic oligomeric intermediates. ${ }^{39}, 40$ However, deposits of $A \beta$ in $A D$ brain do show surrounding dystrophic neuritis indicating that insoluble aggregates may be contributing to neuronal injury. ${ }^{41}$ It is also possible that the large aggregates are in slow equilibrium with surrounding soluble oligomers which may be the actual toxic species (Figure 1). Although, it is not clear that oligomers lie in the same pathway as fibrils as small molecules which inhibit oligomer formation but not fibril formation have 


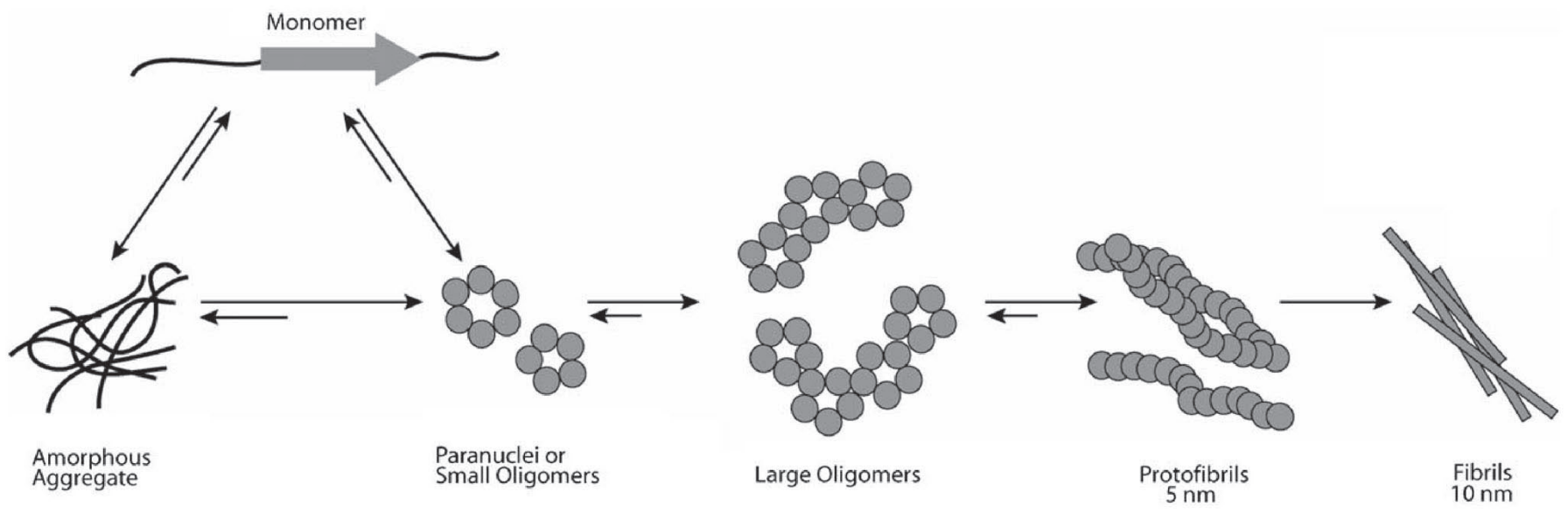

Figure 1. Model for the fibrillogenesis pathway for $A \beta .{ }^{13-18}$

Cliff Stains obtained a Bachelors of Science degree in chemistry from Millersville University under the guidance of Dr. Sandra Turchi. He is currently a graduate student in the Department of Chemistry at the University of Arizona in Tucson. His research interests are in protein design and its application towards targeting nucleic acids and new strategies for identifying inhibitors of protein aggregation.

Kalyani Mondal received her PhD in chemistry in 2006 from the Indian Institute of Technology, Delhi (India) with Dr. M. N. Gupta, working on the applications of smart polymers in protein bioseparation, biocatalysis, and protein folding strategies. She is currently a postdoctoral fellow at the University of Arizona in Tucson. Her current research interests include biocatalysis, protein folding studies, and design of novel approaches for targeting amyloidogenic proteins.

\section{Indraneel Ghosh obtained his BS} degree in chemistry at Hobart College, Geneva, New York and his PhD in chemistry at Purdue University, Indiana in 1998. He was a postdoctoral fellow at Yale University, New Haven until 2001. He is currently an associate professor in the Department of Chemistry at the University of Arizona. His research interests span protein and small molecule synthesis aimed towards the design of inhibitors of protein-protein interactions, hybrid macromolecules, and biosensors for the detection of nucleic acids

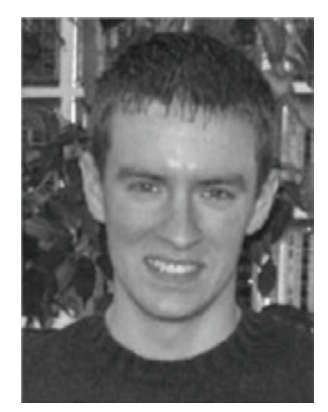

been described..$^{42}$ Hence at the current time the true culprit in these diseases, whether fibrillar or oligomeric, remains to be unequivocally established. Studies on model protein aggregates are also aiding in this effort. ${ }^{16,43-47}$ Many experiments are underway to provide a molecular level understanding of the $A \beta$ oligomers and the data are summarized in Table 1 . This data clearly suggests that even the actual dimensions of these oligomers, whether $2 \mathrm{~nm}, 20 \mathrm{~nm}$, or even micellar, still remains to be established. The data presently suggest that it is very likely that multiple oligomeric species are implicated in the fibrillization pathway.

In comparison to our understanding of the oligomers, ongoing solid state NMR studies from Tycko are rapidly unraveling a true molecular description of the $A \beta_{1-40}$ fibrils. Current work suggests that the amyloid structure favors a $C_{2 z}$ symmetry ${ }^{48}$ that is primarily stabilized by hydrophobic interactions involving L17, F19, A21, A30, I32, L34, and V36 at the "internal quaternary interface" (interface between $\beta$-sheets within a single layer of $A \beta$ molecules) and I31, M35, and V39 at the "external quaternary interface" (interface between $\beta$-sheets of two separate layers of $A \beta$ molecules) (Figure 2). ${ }^{49}$ Salt bridges formed between K28 and D23 also appear to be important for stability, as a lactam crosslink between K28 and D23 has been shown to delay fibrillization..$^{50}$ Once formed, the fibril structure may exclude water as significant changes in structure were not observed when water was removed by freeze-drying. In contrast to some earlier models, Tycko has proposed that native amyloid fibrils are more commonly composed of parallel $\beta$-sheets whereas the antiparallel arrangement may be predominant in fibrils formed from short peptides. ${ }^{49}$ Emerging models of polyglutamine fibrils may also illuminate this issue. ${ }^{51}$

Further biophysical characterization of these intermediates will allow for a structure guided discussion of how different known ligands interact with $A \beta$ and provide a rational template for either stabilizing or disrupting these oligomers. It is perhaps possible that the ligands that target specific oligomers of $A \beta$ will provide a method for trapping these intermediates for structural elucidation. The following discussion will entail a review of amyloid (oligomeric or fibrillar) binding molecules and new molecular approaches for preventing $A \beta$ aggregation and toxicity, which has been the focus of most studies to date. Our review is divided into the following five sections: 1) Natu- 
Table 1. Oligomers of $A \beta$.

\begin{tabular}{ll}
\hline A $\beta$ oligomers & Characteristic feature \\
\hline $\begin{array}{l}\text { SDS stable A } \\
\text { dimers and } \\
\text { trimers }\end{array}$ & $\begin{array}{l}\text { These oligomers are resistant to SDS and protease } \\
\text { (insulin-degrading enzyme, IDE). They were found } \\
\text { to affect synaptic structure and function. }\end{array}$ \\
Protofibrils & $\begin{array}{l}\text { Curvilinear, metastable intermediates which disappear } \\
\text { as fibrils are formed, usually 4-10 nm diameter and up } \\
\text { to } 200 \text { nm in length; have been shown to cause } \\
\text { decrease in levels of reduced MTT in rat neuronal } \\
\text { culture. }\end{array}$
\end{tabular}

Annular Doughnut like structures with inner diameter of assemblies 2.0-2.5 $\mathrm{nm}$ and outer diameter of 8-12 $\mathrm{nm}$.

\begin{tabular}{lc} 
Method of preparation & Ref. \\
\hline $\begin{array}{l}\text { SDS stable dimer and trimers of } A \beta_{1-40} \text { were } \\
\text { detected in cellular media of Chinese hamster }\end{array}$ & 52,53 \\
ovary cells which were transfected with the & \\
APP gene to overexpress $A \beta$. &
\end{tabular}

$A \beta_{1-40}(500 \mu \mathrm{M})$ upon incubation in phosphate buffer, $\mathrm{pH} 7.4$ at room temperature for $1-2$ days

$12,16,42,43$ showed equivalent amounts of protofibrils and low molecular weight oligomers; $A \beta_{1-40}(50 \mu \mathrm{M})$ when incubated with calmidazolium chloride $(100 \mu \mathrm{M})$ for 2 days predominantly formed protofibrils.

The arctic mutant of $A \beta_{1-40}(E 22 G)$ formed 54,55 annular intermediate species more rapidly and to a greater extent as compared to the wild type $A \beta$. These were separated by SEC. Low molecular weight oligomers of $A \beta_{1-42}$ fractionated by SEC consisted of pentamers/hexamers and formed beaded structures.

$\mathrm{A} \beta_{1-40}(350 \mu \mathrm{M})$ when rotated slowly using a rotating cultivator at $37^{\circ} \mathrm{C}$ for $5-7$ days, formed ASPDs. A $\beta_{42}$ ASPDs were prepared by rotating the samples at $4^{\circ} \mathrm{C}$ for $8-10 \mathrm{~h}$. observed in aggregating samples of both $A \beta_{1-40}$ and $A \beta_{1-42}$. Spheroids of size $10-15 \mathrm{~nm}$ were toxic to primary cultures of neuronal cells from rat brain. ASPDs of size $<10 \mathrm{~nm}$ were non-toxic.

$A \beta$-derived diffusible ligands (ADDLs)

Globular intermediates (5-6 nm in diameter), smaller than the annular assemblies. These have been shown to kill mature neurons at nanomolar concentrations. Also evoked neurological dysfunctions well before cellular degeneration.
ADDLs of $A \beta_{1-42}$ have been prepared by incubating $A \beta$ with clusterin for $24 \mathrm{~h}$. In clusterin-free solution, ADDLs of $A \beta$ were prepared by incubating a $100 \mu \mathrm{M}$ solution of $A \beta_{1-42}$ at $4-8^{\circ} \mathrm{C}$ for $24 \mathrm{~h}$ or by diluting an $A \beta$ solution to $50 \mathrm{nM}$ at $37^{\circ} \mathrm{C}$. However, preparation of these species may be dependant on specific conditions such as the use of DMEM-F12 media (without phenol red) and the lack of agitation during incubation.

$A \beta^{\star} 56$ was separated by a high-fidelity extraction procedure that separated protein into extra-cellular, intra-cellular, membrane enriched and insoluble fractions.
Dodecameric assembly of $A \beta_{1-42}$ extracted and purified from extra-cellular fraction from 6 month old transgenic mice. $A \beta^{\star} 56$ disrupted memory when administered to young rats. ral protein ligands that interact with $A \beta, 2)$ Inhibition with modified peptides and peptidomimetics derived from the parent $A \beta$ Sequence, 3) Targeting $A \beta$ with antibodies, 4) Targeting amyloid with in vitro selected peptides and proteins, and 5) Targeting $A \beta$ with small molecules.

\section{Natural Protein Ligands that Interact with $A \beta$}

Though the mechanism of toxicity of $A \beta$ in the cellular environment is still not clearly understood, numerous experiments have been conducted to determine possible natural protein binding partners of $A \beta$. Some of these natural ligands may be a missing link between $A \beta$ accumulation and cellular toxicity (Table 2). A few of these interacting proteins which have been studied in greater detail are discussed below.

The conventional yeast two-hybrid system, used to detect protein-protein interactions in vivo, has been applied to $A \beta .^{57}$ This system was able to specifically report on the interaction of $A \beta$ monomers in the yeast nucleus. A control bait protein which contained double Phe to Thr substitutions, at residues 19 and 20 of the hydrophobic core, did not produce apprecia- ble signal, indicating that the observed $A \beta$ interactions were likely specific.

Subsequently a similar yeast two-hybrid system was also used to identify an endoplasmic-reticulum associated binding protein (ERAB) from human brain and HeLa cell cDNA libraries. ${ }^{58}$ ERAB was shown to co-precipitate with $A \beta$ and suppression of ERAB activity led to a decrease in cellular toxicity of $A \beta$. This protein was identified as an alcohol dehydrogenase and was later termed $A \beta$-binding alcohol dehydrogenase or ABAD. A crystal structure of $A \beta$-bound ABAD has been solved. ${ }^{59}$ This crystal structure shows that the active site is severely perturbed such that NAD binding is prevented. An ABAD derived peptide was shown to suppress $A \beta$ toxicity while the overexpression of $A B A D$ in the presence of $A \beta$ led to an increase in oxidative stress in transgenic mice. An ELISA based screen has identified small molecule inhibitors of the $A \beta-A B A D$ interaction. ${ }^{60}$ The most potent of these inhibitors had an $I C_{50}$ value of $<10 \mu \mathrm{M}$ but its ability to decrease the cytotoxicity of $A \beta$ remains to be demonstrated.

The early observations of increased phosphorylation of proteins in Alzheimer's patients led to the hypothesis that $A \beta$ may directly perturb the activities of certain kinases. Indeed, the ac- 
a)

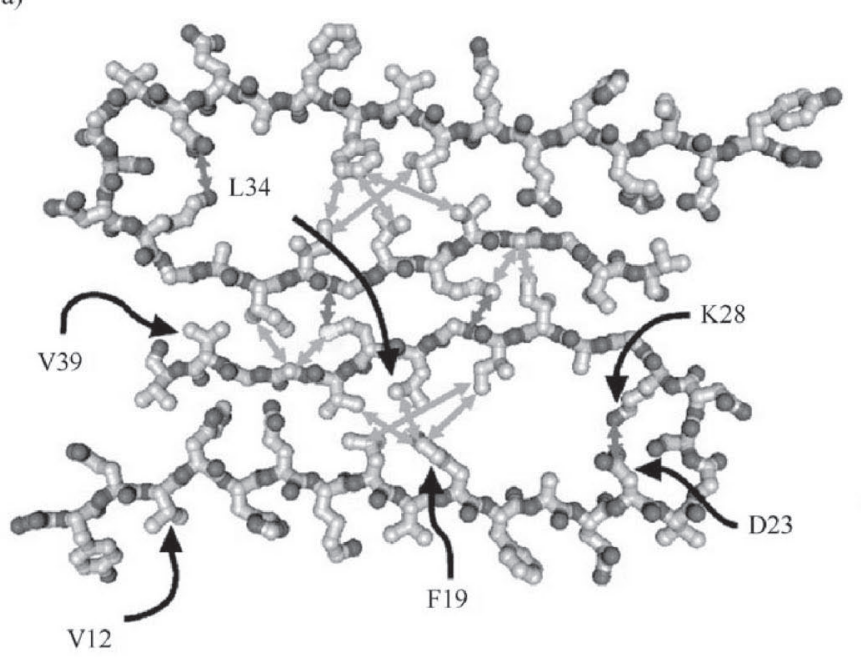

c)

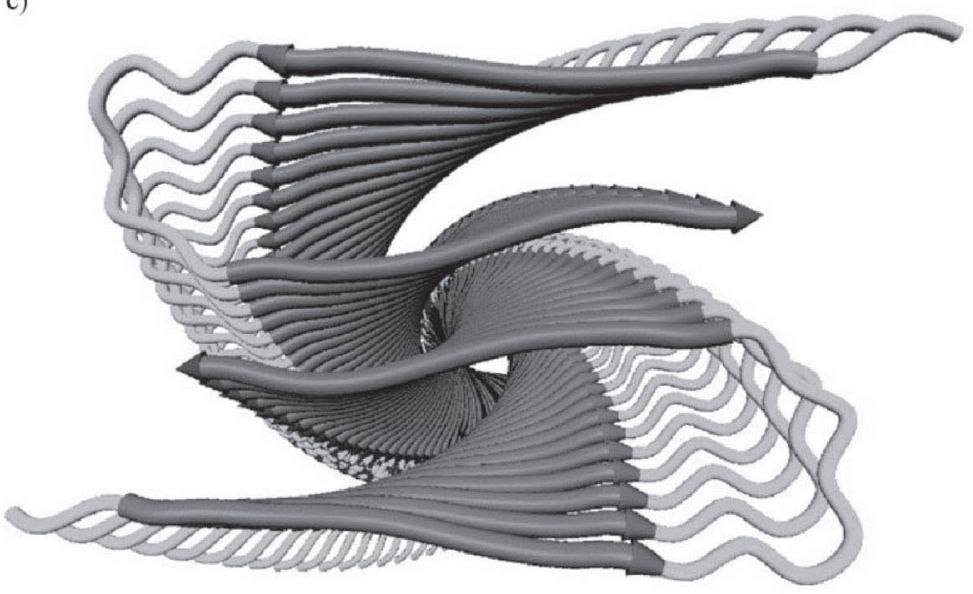

b)

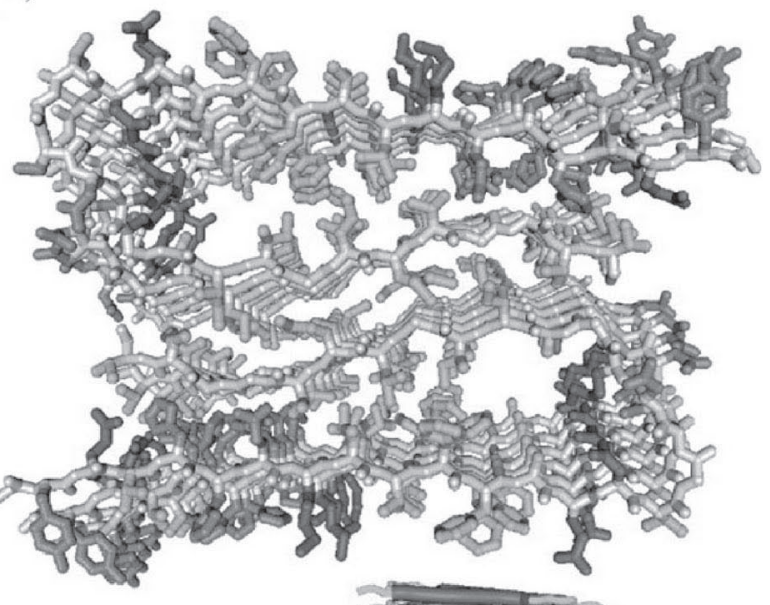

d)

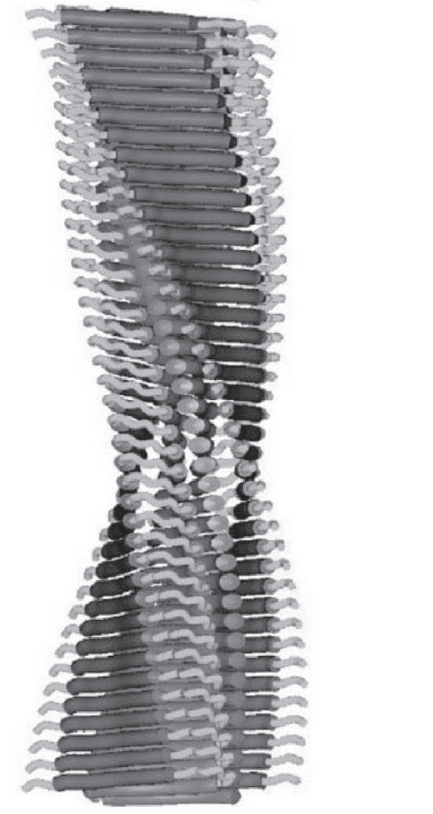

Figure 2. Structural model for the protofilament in $A \beta_{1-40}$ fibrils prepared with gentle agitation a) All-atom representation of a pair of peptide molecules. Residues $10-22$ and $30-40$ have $\beta$-strand conformations, forming two separate in-register, parallel $\beta$-sheets. The protofilament is a fourlayered $\beta$-sheet structure with $\mathrm{C}_{2}$ symmetry about its long axis. Double-headed arrows indicate side chain-side chain and side chain-backbone contacts established by $2 \mathrm{D}{ }^{13} \mathrm{C}-{ }^{13} \mathrm{C}$ NMR measurements or ${ }^{15} \mathrm{~N}-{ }^{13} \mathrm{C}$ dipole-dipole couplings. b) Average structure resulting from ten independent molecular dynamics/energy minimizations runs on a cluster of twelve peptides, with interatomic distance and backbone torsion angle restraints dictated by solid-state NMR data. The four-layered $\beta$-sheet structure is stabilized primarily by hydrophobic interactions in the core of the protofilament. Polar and charged side-chains are on the exterior, with the exception of oppositely charged K28 and D23 side-chains, which form salt bridges. c) and d) Cartoon representations with residues 12-21 and 30-40 shaded. (Reprinted with permission from Cambridge University Press)

tivities of purified casein kinase I and II (CKI and II) have been shown to be increased in a concentration dependent manner by $A \beta$ when monitoring phosphorylation of casein. ${ }^{61}$ Overexpression of a constituently active form of CKI has been shown to increase the amount of $A \beta$ in brain tissue cultures. ${ }^{86}$ Three different $\mathrm{CKI}$-specific inhibitors were shown to decrease the amount of $A \beta$ produced. This approach has the potential for identifying novel therapeutics for the treatment of Alzheimer's if the $\mathrm{CKI} / \mathrm{A} \beta$ interaction correlates with cognitive failure. It is still to be established whether the observed effects are directly or indirectly mediated by $A \beta$ in a physiological context.

The activity-dependent neuroprotective protein (ADNP) was discovered by screening cDNA libraries by antibody mat- uration. A very short eight amino-acid segment of this protein, NAPVSIPQ, was shown to protect neuronal cells against $A \beta$ at femtomolar concentrations. ${ }^{63,87} \mathrm{~A}$ study has shown that intranasal administration of this peptide can significantly reduce the levels of $A \beta$ in transgenic mice model of Alzheimer's. ${ }^{9}$ Again it is very possible that this peptide does not function by direct interaction with $A \beta$.

Transthyretin, a protein in the cerebral fluid, was found to bind to $A \beta$ through fractionation of an $A \beta$-binding activity. ${ }^{85}$ Subsequently, transgenic mice containing a mutation in the APP gene predisposing them to early onset $A D$, the Swiss mutation, were found to overexpress transthyretin. ${ }^{88}$ This overexpression correlated with a decrease in the progression of $A D$ 
Table 2. Biomolecules that bind $A \beta$.

\begin{tabular}{|c|c|c|}
\hline Biomolecule & Method of Discovery/Evidence & Ref. \\
\hline A $\beta$-Binding Alcohol Dehydrogenase & Yeast two-hybrid screen using a human brain cDNA library & 58 \\
\hline$A \beta-$ Related Death-Inducing Protein & Yeast two-hybrid screen using a human brain cDNA library & 62 \\
\hline$\alpha_{1}$-Antichymotrypsin & Antigen maturation of a cDNA library & 64 \\
\hline a-7 Nicotinic Acetylcholine Receptor & Co-immunoprecipitation from human brain tissue & 65 \\
\hline Amyloid Precursor Protein & Co-precipitation with $A \beta$ in rat hippocampal cultures & 8 \\
\hline Apolipoprotein E4 & Amyloid deposition in a mice model correlated to Apo E4 expression & 68,69 \\
\hline Apolipoprotein J & Affinity purification from cerebral spinal fluid by immobilized $A \beta$ & 70 \\
\hline Casein Kinase I and II & In vitro phosphorylation assay using casein & 61 \\
\hline Catalase & In vitro binding assay to monitor catalase binding & 71 \\
\hline $\begin{array}{l}\text { Collagen-like Alzheimer Amyloid Plaque } \\
\text { Component }\end{array}$ & $\begin{array}{l}\text { Isolation of an } A \beta \text {-associated antigen further fractionation and identification } \\
\text { using proteolytic cleavage and protein sequencing }\end{array}$ & 72 \\
\hline Heat Shock Proteins 70 and 90 & In vitro inhibition of $A \beta$ assembly & 75 \\
\hline Insulin Receptor & Competes with insulin for binding to the insulin receptor & 76 \\
\hline Integrins & Inhibition of cell adhesion, of human neuroblastoma cells, to fibronectin by $A \beta$ & 77 \\
\hline N-Methyl-D-Aspartate Receptors & Internalization of $A \beta$ in cultured hippocampal slices & 78 \\
\hline p75 Neurotrophin Receptor & Co-immunoprecipitation, using $\mathrm{NIH}-3 \mathrm{~T} 3$ cells, of radiolabeled $\mathrm{A} \beta$ & 79 \\
\hline Protein Kinase C & Tissue culture phosphorylation assay & 80 \\
\hline Pyruvate Dehydrogenase & Enzyme activity in isolated rat brain mitochondria & 66 \\
\hline $\begin{array}{l}\text { Receptor for Advanced Glycation End } \\
\text { Products }\end{array}$ & Isolation of a $A \beta$-binding activity and protein sequencing & 81 \\
\hline Scavenger Receptors & Microglial uptake & 82 \\
\hline Serpin-Enzyme Complex Receptor & Competitive inhibition of a radiolabeled ligand binding by $A \beta$ in human hepatoma cells & 83 \\
\hline
\end{tabular}

symptoms such that disease onset was delayed. Forty-seven individual point mutants of transthyretin have been analyzed for $A \beta$-binding and inhibition of fibril formation. ${ }^{89}$ All but two mutants, G42 and $P 55$, bound $A \beta$, localizing the $A \beta$-binding activity to this region. Studies suggest that transthyretin decreases the rate of fibril formation by decreasing the lateral association of fibrils as well as decreasing the rate of elongation of fibrils. ${ }^{90}$ These data would indicate that, at concentrations of $2 \mu \mathrm{M}$ transthyretin and $140 \mu \mathrm{M} \mathrm{A} \beta$, transthyretin binds to the fibrillar form of $A \beta$ arresting the formation of plaques. This study is quite interesting, given that transthyretin itself is directly implicated in a different misfolding disease and one of the few instances where small molecules are known to inhibit aggregation by stabilizing the native state. ${ }^{91}$

From the above studies with possible natural protein ligands of $A \beta$, it is clear that there are many possible candidate proteins that directly or indirectly interact with $A \beta$ and modulate its activity. With a growing list of candidate proteins the physiological role of $A \beta$ will likely be established, resulting in new methods for diagnosing and possibly treating AD. Structural details of true and potent $A \beta$ bound complexes will likely provide the necessary molecular templates for the design of useful diagnostics and therapeutics as has been realized for transthyretin.

\section{Inhibition with Modified Peptides and Peptidomimetics Derived from the Parent $A \beta$ Sequence}

Several elegant strategies have been used to rationally design peptidic inhibitors of $A \beta$ aggregation, some of which are discussed in detail (Table 3). Many of these approaches rely on using fragments of the parent $A \beta$ sequence as recognition elements in a dominant negative fashion. Typically, fibril disrupting chemical elements are incorporated into $A \beta$ derived peptides in the form of $\mathrm{N}$ - or C-terminal modifications, conformationally constrained amino acids, or modifications to the peptide backbone. These concepts have also been applied to $D$-amino acid variants of the parent $A \beta$ sequence. These different molecular design strategies are discussed below.

\section{N- and C-terminal modifications}

Inhibitors of fibril formation based on the hydrophobic region of $A \beta$ are the most prevalent. Initial work in this area identified the KLVFF motif ${ }^{92}$ as capable of inhibiting fibril formation. A variant of this core domain (Table 3 a) containing a polycationic disrupting region appended to the $C$ terminus, KLVFFKKKKKK, was shown to increase the rate of fibril formation and cell viability. ${ }^{93},{ }^{94}$ The rate of fibril forma- 
Table 3. Designed peptide inhibitors of $A \beta$.

A $\beta$ (1-42): DAEFRHDSGYEVHHQKLVFFAEDVGSNKGAIIGLMVGGVVIA

$\begin{array}{ll}\text { a) N- and C-Terminal Modifications: } \\ \text { Peptide } & \text { Activity } \\ \text { KLVFF } & \text { Inhibited fibril formation } \\ \text { KLVFFKKKKKK } & K_{\mathrm{d}}: 40 \mu \mathrm{M}, \mathrm{SPR} \\ \text { KLVFFKKKK } & K_{\mathrm{d}}: 37 \mu \mathrm{M}, \mathrm{SPR} \\ \text { KLVFFKK } & K_{\mathrm{d}}: 80 \mu \mathrm{M}, \mathrm{SPR} \\ \text { KLVFFEEEKKK } & K_{\mathrm{d}}: 1.3 \mathrm{mM}, \mathrm{SPR} \\ \text { KKKKLVFF } & K_{\mathrm{d}}: 180 \mu \mathrm{M}, \mathrm{SPR}\end{array}$

DDX3 Reduced toxicity in neuroblastoma cells

RIIGL Inhibited fibril formation and toxicity

$\mathrm{Pr}_{\mathrm{IIGL}} \quad$ Was toxic in cellular assays

b) Conformationally Constrained Peptides:

$\begin{array}{ll}\text { Peptide } & \text { Activity } \\ \text { iA 55 } & \text { Inhibited fibril formation, disassembled fibrils, } \\ & \text { and reduced toxicity }\end{array}$
and reduced toxicity

AMY-1

No fibril formation after 4.5 months

AMY-2

Rapid formation of large nonfibrillar aggregates

\author{
Structure \\ KLVFF \\ KLVFFKKKKKK \\ KLVFFKKKK \\ KLVFFKK \\ KLVFFEEEKKK \\ KKKKLVFF
} (IIIGL

Structure

LPFFD

Ref.

Ref.

94 94 4

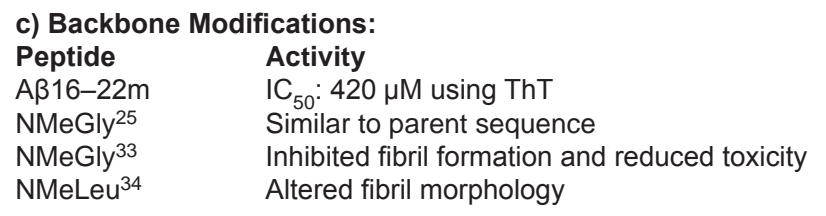

Aß16-20e

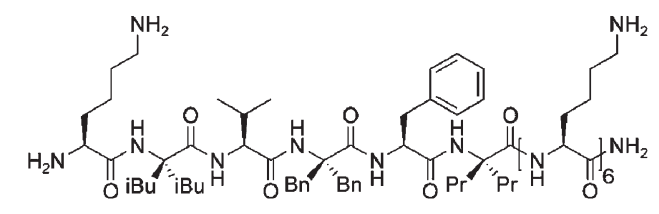

\section{Structure}

$\mathrm{K}_{\mathrm{NMe}} \mathrm{LV}_{\mathrm{NMe}} \mathrm{FF}_{\mathrm{NMe}} \mathrm{AE}$ NME GSNKGAIIGLM

GSNKGAII $_{\mathrm{NMe}}$ GLM

GSNKGAIIG $_{\mathrm{NMe}^{2}} \mathrm{LM}$

Ref.

Ref.
98

99

99

99

(1)

d) d-Amino Acid Peptides:

Peptide Activity

SEN $301 \quad$ Produced multiple types of fibrils

Structure<smiles>CC(C)C[C@H](C(N)=O)N(C)C(=O)C(NC(=O)[C@@H](NC(=O)C(CC1CCCCC1)NC(=O)[C@@H](N)C1CCCCC1)C1CCCCC1)C1CCCCC1</smiles>

Ref.

102<smiles>CC(C)CC(C(N)=O)N(C)C(=O)[C@@H](NC(=O)C(NC(=O)C(N)CC1CCCCC1)C1CCCCC1)C1CCCCC1</smiles> 
Table 3. Designed peptide inhibitors of $A \beta$ (continued).

A $\beta$ (1-42): DAEFRHDSGYEVHHQKLVFFAEDVGSNKGAIIGLMVGGVVIA

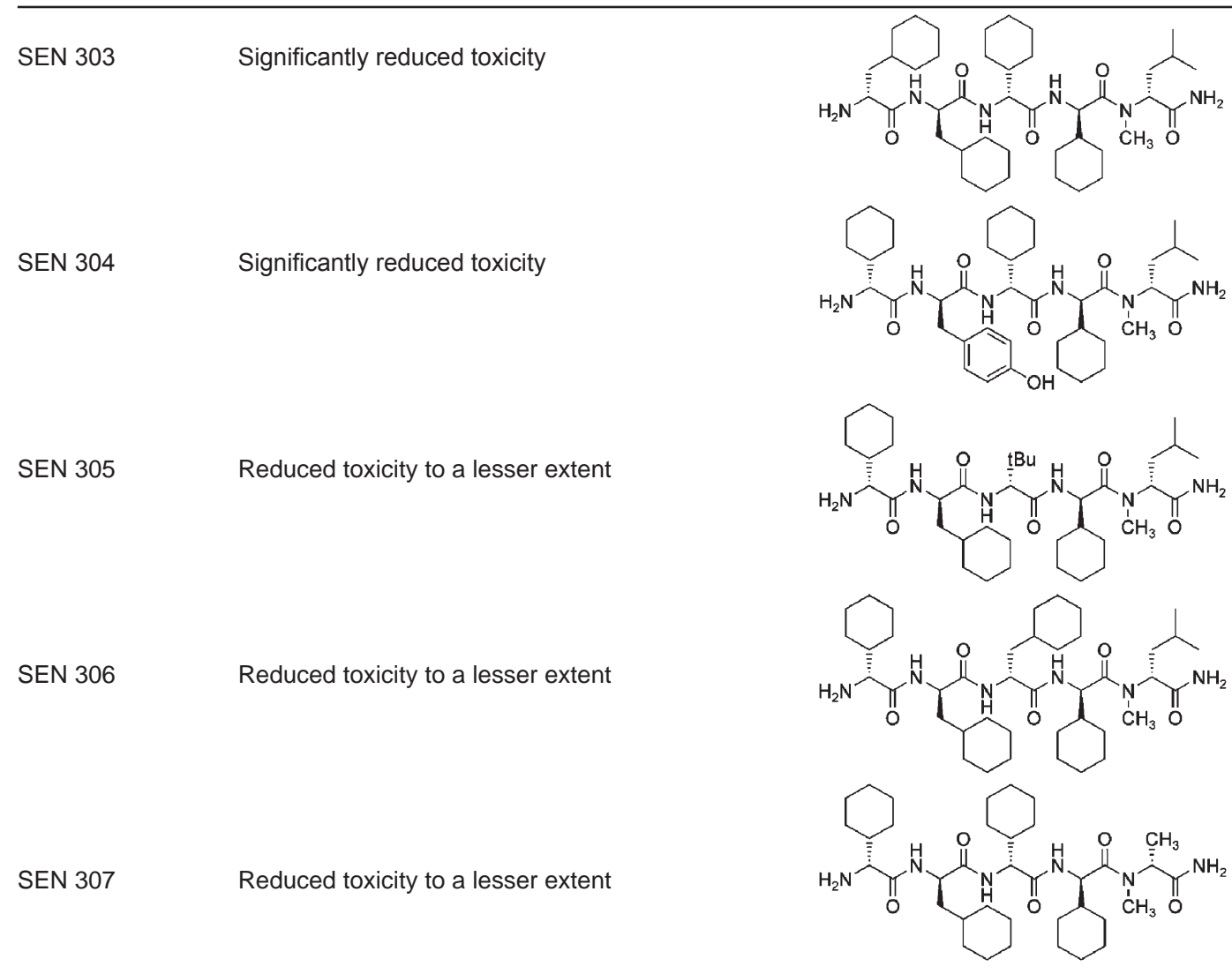

tion increased with the number of lysine residues as follows: KLVFFKK $<$ KLVFFKKKK $<$ KLVFFKKKKKK. The effect of charge distribution and the orientation of the disrupting element was also verified using KLVFFEEEKKK and KKKKLVFF. Both of these peptides bound with less affinity to $A \beta$ as determined by SPR. The ability of these peptides to accelerate fibril formation while decreasing toxicity is very intriguing, and suggests that the new fibrils are not toxic or that they are no longer in equilibrium with the toxic oligomeric intermediates. A peptide corresponding to $A \beta_{31-34}$ when appended to a $\mathrm{N}$-terminal propionyl group ( $\mathrm{Pr} I \mathrm{IGL})^{95}$ was shown to form fibers and was toxic to neuroblastoma cells. However, replacement of the propionyl group with an arginine (RIIGL) resulted in a peptide which inhibited fibril formation and reduced toxicity of $A \beta$, possibly sequestering the toxic oligomeric species and preventing interactions at the cell membrane. The above studies are quite significant as they suggest multiple new routes to interfere with $A \beta$ assembly and may also be starting points for designing reagents that trap and stabilize intermediates that can be further studied at the molecular level.

\section{Conformationally constrained peptides}

Building on the observation that the hydrophobic core of $A \beta$ was capable of inhibiting fibril formation, a conformationally constrained $\beta$-sheet breaker peptide has been designed. ${ }^{96}$ The peptide, iA $\beta 5$, contains a single proline residue in the hydrophobic recognition sequence which is thought to disrupt fibril formation through unfavorable steric interactions or alternatively by redirecting $A \beta$ assembly in alternate nontoxic arrangements. This peptide was reported to disassemble fibrils in vitro and to increase cell viability.

A new class of conformationally constrained peptides which contained $\alpha, \alpha$-disubstituted amino acids (Table $3 \mathrm{~b}$ ) have been synthesized. ${ }^{97}$ These $\alpha, \alpha$-disubstituted amino acids were incorporated in such a way that one face of the peptide would be sterically blocked. The peptide AMY-1 was shown to abrogate fibril formation for up to 4.5 months, whereas AMY-2 was shown to produce nonfibrillar aggregates. The authors suggest that this difference in activity may be attributed to the positioning of the hydrophilic tails in each peptide, such that the polyly- 
sine tail at the $\mathrm{C}$ terminus disrupts amyloid aggregation by interfering with committed assembly steps within the N-terminal hydrophobic region.

Another interesting approach in this area of $A \beta$ mimetics is the substitution of alternating amide hydrogens with methyl groups (Table $3 \mathrm{c}$ ). This approach in principle serves to cap oligomeric domains and prevent the $\beta$-sheet propagation necessary for $A \beta$ fibrillization. Furthermore, these $N$-methylated peptides tend to have increased solubility (by preventing self aggregation), increased resistance to proteolytic degradation, and the possibility for increased blood-brain barrier penetration. Meredith and co-workers designed inhibitors based on the much studied hydrophobic core $A \beta$ motif KLVFFAE, containing $\mathrm{N}$-methylated amino acids. ${ }^{98}$ These peptides were found to inhibit fibril formation and disassemble preformed fibrils in vitro. The most potent inhibitor contained alternating sites of $\mathrm{N}$ methylation, $A \beta 16-22 \mathrm{~m}$. N-methylated $A \beta$ derived peptides have also been reported by Doig based on $A \beta_{25-35}$ (GSNKGAIIGLM). ${ }^{99}$ The authors showed that NMeGly ${ }^{25}$ had no activity and actually showed similar aggregation and toxicity levels as that of the wild-type sequence. However, NMeGly ${ }^{33}$ was shown to completely inhibit fibril formation, disassemble preformed fibrils, and reduce cellular toxicity. These results would imply that the position of $\mathrm{N}$-methylation is crucial for efficacy and likely maps to a critical region of the growing amyloid fibril (Table 3). Meredith and co-workers have also investigated the effect of replacing the amide backbone with ester bond surrogates at alternating positions. ${ }^{100}$ The peptide, $A \beta 16-20$ e, was synthesized and shown to inhibit fibril formation and disassemble fibrils in vitro. This ester containing peptide likely functions by preventing hydrogen-bond propagation as seen in the alternating $\mathrm{N}$-methylation approach. What is also very interesting is the reported disassembly of pre-existing fibers, which may suggest that many of these peptides can bind at the end of the fibrils and possibly serve to influence the thermodynamic equilibrium between oligomers and fibrils.

\section{D-Amino acid peptides}

Doig and coworkers systematically explored the structure-activity relationship of numerous peptides based on the KLVFFA sequence. ${ }^{102}$ The initial library of KLVFFA peptides revealed that peptides containing the core LVFFL motif were the most effective at inhibiting fibrillization. Efficacy was increased when peptides were constructed entirely from D-amino acids and singly methylated at the first and fifth positions or doubly methylated at both positions. Using this information the authors developed four new libraries to ascertain the effects of the position of $\mathrm{N}$-methylation and amino acid preference. The authors found that large branched hydrophobic side chains were preferred at positions 1-4 and that a single $\mathrm{N}$-methylated site was sufficient for fibril inhibition. All peptides from this final compound library were shown to decrease toxicity in PC12 cells using the MTT assay. The most potent compound, SEN 304, was determined to be more active than the $\beta$-sheet breaker peptide ${ }^{96}$ as determined by ThT and MTT assays.

Other interesting approaches ${ }^{105}$ have targeted $A \beta$ utilizing peptides based on the GxFxGxF scaffold expected to interact with the $C$ terminus of $A \beta$. The most active compound RGTWEGKW was shown to inhibit fibril formation and re- duce cellular toxicity. The authors propose that alternating hydrophilic-hydrophobic nature of this peptide may help to disrupt $A \beta$ aggregation. $A$ different approach has utilized the so-called surface tension-modifying peptides ${ }^{106}$ that actually increased the rate of $A \beta$ fibril formation several-fold. It remains to be seen if such peptides prevent the build up of the toxic soluble intermediates by sequestering $A \beta$ in the fibril state.

Thus, it is clear that the considerable efforts in the rational design of $A \beta$-targeting molecules based on the parent $A \beta$ sequence have been quite fruitful in providing a large class of compounds with different modes of activity. ${ }^{107}$ These peptidomimetic molecules by themselves or with further modifications provide a class of reagents that may help elucidate the mechanism of amyloid aggregation, perhaps by trapping intermediates, as well as providing inroads into the design of diagnostic and therapeutic reagents.

\section{Targeting $A \beta$ with Antibodies}

Antibodies, because of their specificity and conformation dependence, have been attractive choices for potential therapeutic strategies for the treatment of AD. They are now also being used to distinguish between fibrils and prefibrillar intermediates in the aggregation pathway. The recent developments in $A \beta$ immunotherapy and in the use of site-directed antibodies as tools for understanding the amyloid aggregation pathway is elaborated in the following two subsections:

\section{$A \beta$ Immunotherapy}

Antibodies generated against $A \beta_{1-42}$ were shown to lower cerebral amyloid plaques in mouse models. ${ }^{108}$ However, a clinical trial using $A \beta_{1-42}$ fibrils for active immunization was halted when $\sim 6 \%$ of the patients developed meningoencephalitis, ${ }^{109,} 110$ possibly due to a potent T-cell mediated immune response. To avoid the risk of such an adverse autoimmune response and to develop safer vaccines, newer strategies are being tested in $A \beta$ immunotherapy using the $N$ terminus $A \beta_{1-15}$ fragment which has been demonstrated to lack T-cell reactivity in mice and humans. ${ }^{111,112}$ As a monovalent linear peptide would not be an effective immunogen, Agadjanyan et al. synthesized the $A \beta_{1-15}$ fragment in tandem with an HLA DR binding peptide (PADRE). ${ }^{113}$ PADRE is a 13-residue nonnatural peptide that is a potent T-cell epitope. PADRE-A $\beta_{1-15}$ was synthesized on a multiple antigenic peptide (MAP) platform to enhance the immune response by a multivalent effect. Antibodies induced by PADRE-A $\beta_{1-15}$-MAP were specific to $A \beta$ and did not bind to the MAP backbone or PADRE. These antibodies prevented $A \beta$ fibrillization and the splenocytes from mice showed T-cell stimulation only to PADRE and not to A $\beta$ T-cell epitopes. In a similar approach, bacterial thioredoxin (Trx) was used as a scaffold to link four repeats of $A \beta_{1-15 .}{ }^{114}$ The anti-Trx $(A \beta 15)_{4}$ antibody generated against this epitope bound to $A \beta_{1-}$ ${ }_{42}$ fibrils and oligomers but not monomers and reduced $A \beta$ pathology in transgenic AD mice.

In a complementary approach, Maier et al. have tested peptide immunogens consisting of tandem repeats of di-lysine linked $A \beta_{1-15}$ sequences $\left(A \beta_{1-15}-K K-A \beta_{1-15}\right)$ and found them to be more effective in boosting the immune response as com- 


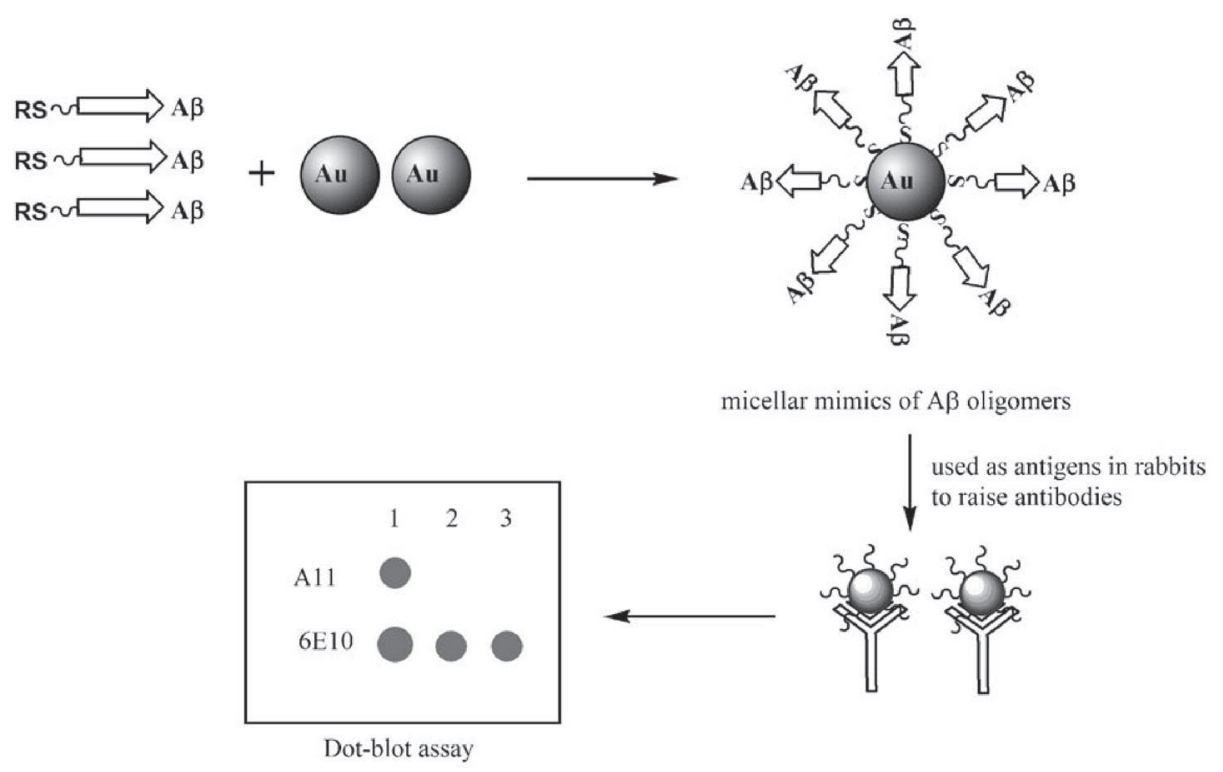

A11: anti-oligomer antibody 6E10: non-specific antibody against $\mathrm{A} \beta$

Figure 3. Production of antibodies that specifically bind $A \beta_{1-40}$ oligomers. In the dot blot assay, anti-oligomer antibody (A11) binds only to (1) the oligomeric intermediate of $A \beta_{40}$ and does not show reactivity against (2) $A \beta_{40}$ fibrils or (3) $A \beta_{40}$ monomers, whereas $6 E 10$ recognized all species of $\mathrm{A} \beta$.

pared to $A \beta_{1-15}$ itself. 42 Of these, $A \beta_{1-15}-K K-A \beta_{1-15}$ and RGD$A \beta_{1-15}-K K-A \beta_{1-15}$ significantly reduced $A \beta$ plaque load in transgenic $A D$ mice without splenocyte proliferation. ${ }^{115}$ Animals immunized with $A \beta_{1-15}-K K-A \beta_{1-15}$ also showed improved acquisition of memory as compared to the controls. Thus, these new studies using active immunization show much promise but will ultimately have to demonstrate safety and efficacy in clinical trials. It would also be interesting to pursue the in vitro study of the individual antibodies elicited by these active immunization regimes and clearly establish the molecular mechanism for their interactions with $A \beta$.

\section{Antibodies as probes of $A \beta$ intermediates}

Antibodies are also emerging as useful chemical probes for delineating the steps in $A \beta$ assembly. As mentioned earlier, many reports suggest the soluble oligomers and not the fibrils are the toxic species, ${ }^{13}$ thus the interaction of specific antibodies with $A \beta$ are being used to directly probe such intermediate species for a better understanding of the aggregation pathway. O'Nuallain and Wetzel described the generation of two conformation-specific antibodies, WO1 and WO2 that bound to $A \beta_{1-}$ ${ }_{40}$ fibrils but not soluble $A \beta$ species, even in the presence of a large excess of $A \beta_{1-40}$ monomers. ${ }^{116}$ These antibodies were also able to bind amyloid fibrils of other proteins, which again strongly suggests that the final fibrillar form of $A \beta$ is common to numerous proteins that form fibers. To generate polyclonal antibodies against the so-called $A \beta$-derived diffusible ligands (ADDLs), the toxic soluble oligomers of $A \beta_{1-42}$, Lambert et al. incubated $A \beta$ solution for $48 \mathrm{~h}$ at $4{ }^{\circ} \mathrm{C}$, centrifuged at $14000 \mathrm{~g}$

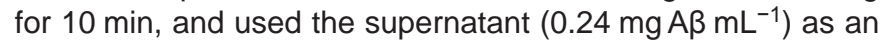
immunogen. ${ }^{117}$ This supernatant (defined as ADDL preparation) was free of amyloid fibrils and contained a mixed population of spherical oligomers and monomers of $A B$ (as observed by AFM). The antibodies produced recognized trimers, tetramers, and surprisingly also fibrils of $A \beta_{1-42}$ in dot-blot assays. At higher concentrations the antibody was also found to bind monomers. A more specific antibody probe against such oligomers was prepared in a controlled fashion by Kayed et al. ${ }^{118}$ They reacted gold nanoparticles with a C-terminal thioester containing $A \beta_{1-40}$ to synthesize micellar mimetics of $A \beta$ oligomers (Figure 3 ). These micellar mimetics were similar in size when compared to the soluble intermediates and were used to immunize rabbits. The anti-oligomer antibody generated did not react with monomers or fibrils of $A \beta_{1-40}$, but was reported to exclusively precipitate $A \beta_{1-40}$ oligomers in dot-blot assays. The smallest oligomeric species recognized by this antibody had an apparent molecular weight of $40 \mathrm{kDa}$ on size exclusion chromatography, which corresponds to an octamer of $A \beta_{1-40}$. The anti-oligomer antibody is now commercially available from Invitrogen and is being utilized to delineate the mechanism of small molecules that influence $A \beta$ oligomerization, which is discussed in Section 5 of this review. ${ }^{42}$ Again, it is surprising that this new anti-oligomer antibody also recognized soluble intermediates of other amyloidogenic proteins and peptides. These results in conjunction with the $A \beta$ fibril targeting antibody suggest that not only are the final fibrillar structures similar for different proteins but so are many of the intermediates.

\section{Targeting Amyloid with in vitro Selected Peptides and Proteins}

Though antibodies are clearly the first established choice for targeting proteins and peptides, phage displayed peptides and protein scaffolds have also emerged as an alternate route for targeting $A \beta .{ }^{119}, 120$ Phage display approaches generally enrich for an immobilized protein of interest and a complicated 


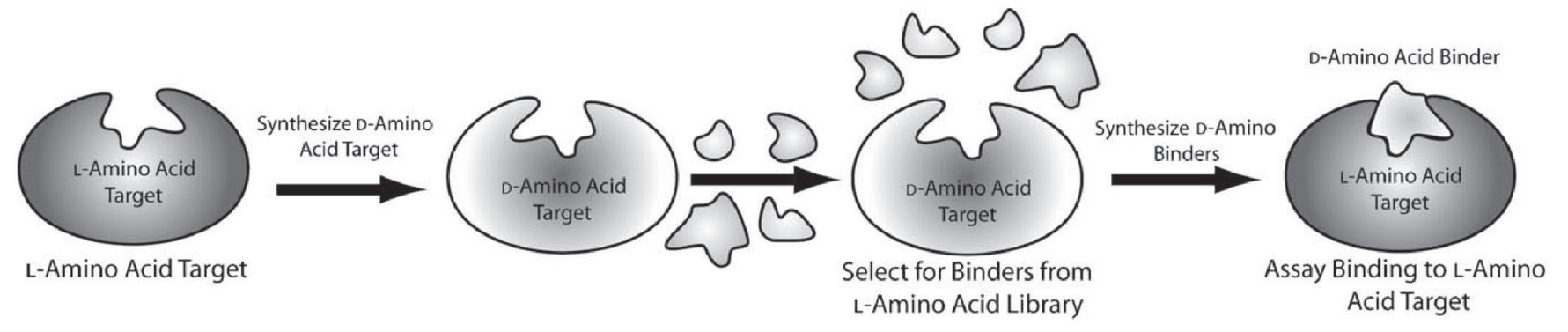

Figure 4. The general scheme for selecting mirror image peptides is shown.

Table 4. Peptides selected for $A \beta$ binding.

\begin{tabular}{lll}
\hline & \multicolumn{1}{c}{ Selected Peptide Inhibitors } \\
\hline Peptide & Results & Ref. \\
DWGKGGRWRLWPGASGKTEA & Binds $A \beta$ in vitro with a $K_{d}$ of $60 \mathrm{nM}$ by ELISA & 121 \\
PGRSPFTGKKLFNQEFSQDQ & Stains $A \beta$ deposits & 121 \\
D-QSHYRHISPAQV & Binds $A \beta$ in vitro with a $K_{d}$ of $400 \mathrm{nM}$ by fluorescence & 122 \\
FYLKVPSSLHHHH & Prefers monomeric $A \beta$ & 123 \\
GRDKLVFFHHHH & Prefers monomeric $A \beta$ & 123 \\
NYSKMIFSHHHH & Prefers aggregated $A \beta$ & 123 \\
HNHKLVFFHHQH & Prefers aggregated $A \beta$ & 123 \\
MAQTFWLSIQGKTLYWQIRIYAID- & Inhibits fibril formation of $A \beta$ & 124 \\
\hline
\end{tabular}

immunization protocol is not necessary. Results in this area are tabulated (Table 4) and discussed in this section.

In one of the earliest studies in this area, a library of 20 residue peptides was used to select for $A \beta_{1-40}$ binding using phage display. ${ }^{121}$ Only two peptides were identified from this selection and were shown to be capable of staining $A \beta$ deposits. The sequences suggested an aromatic rich motif: (W/F) $\mathrm{X}_{5}(\mathrm{~W} / \mathrm{F}) \mathrm{X}_{2 / 3}(\mathrm{~W} / \mathrm{F})$ which sometimes contained proline residues suggesting a turn conformation.

Mirror-image phage display allowing for the eventual identification of D-amino acid peptides (Figure 4) has been utilized for the discovery of peptides which bind $A \beta .{ }^{125}$ In this strategy a synthetic D-amino acid version (enantiomer) of the target is immobilized, against which a library containing L-amino acid peptides is selected. Once L-amino acid binders are identified, their D-enantiomers are synthesized and interrogated for binding to the L-amino acid target. This is an elegant approach for the development of peptide inhibitors that are resistant to proteolytic cleavage. Using this approach Wiesehen and co-workers immobilized the full length D-enantiomer of $A \beta_{1-42}$ and selected binders from a phage-displayed peptide library. ${ }^{122}$ The D-enantiomer of the most prevalent sequence from this selection, D-QSHYRHISPAQV, binds the natural L-enantiomer of $A \beta$ (1-42) with an apparent dissociation constant of $400 \mathrm{nM}$, though the stoichiometry of the complex remains to be ex- plored in detail. Appropriately labeled analogues of this peptide were also shown to be effective in staining $A \beta$ deposits in brain tissues. However, the effect of this peptide on $A \beta$ aggregation has not been determined to date.

Phage display using the KLVFF core motif was used to identify peptides which bound different species in the $A \beta$ aggregation pathway. ${ }^{123}$ Two libraries were used to assess the effect of polar residues on binding and the sequence requirements of the core motif. Both libraries were screened against aggregated and monomeric $A \beta$. Surprisingly, peptides selected for binding to the monomeric species did not effect the aggregation rate whereas those selected for binding to the aggregated species did. The ability of these peptides to promote aggregation correlated with their relative affinities for the $\mathrm{N}$ terminus of $A \beta$. The observation that peptides can be selected to bind specifically to different intermediates in the $A \beta$ aggregation pathway opens up the possibility of producing tractable reagents for deciphering amyloid aggregation kinetics and thermodynamics.

We have recently utilized phage display to isolate variants of a small $\beta$-sheet scaffold ${ }^{126}$ that likely binds to intermediates in the aggregation pathway of $A \beta .^{124}$ In this selection scheme (Figure 5) a phage-displayed library containing eight randomized residues on the first two $\beta$-strands of the small IgG binding protein, HTB1, was generated. This library was first
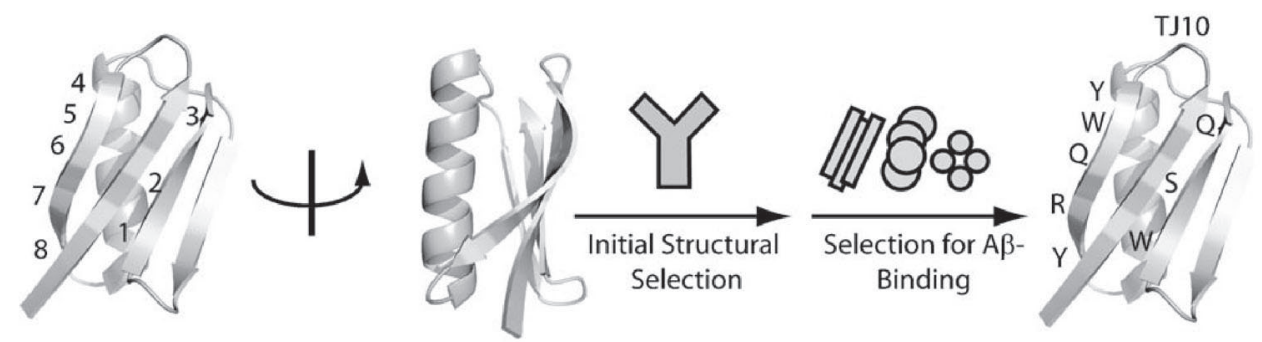

Figure 5. Selection of $\beta$-sheet displaying small proteins (HTB1 variants) which bind A $\beta$. Eight positions on two $\beta$-sheets are randomized. An initial structural selection, using the helical face, against lgG maintains the native fold. Subsequent rounds of selection for $A \beta$-binding, using the $\beta$-sheet face, yielded the TJ10 variant. 
enriched for proteins that maintain the parent fold by IgG selection and subsequently selected against $A \beta_{1-40}$ (Figure 5). Several proteins were isolated, notably one of these small $\beta$-sheet rich proteins, TJ10, maintained its structure and was shown to inhibit $A \beta_{1-40}$ aggregation in a stoichiometric manner. Initial dynamic light scattering experiments suggest that TJ10 interacts and likely traps soluble oligomers of $A \beta_{1-40}$ that range from $10-300 \mathrm{~nm}$ in diameter.

This approach has the potential for providing a structural handle on an $A \beta_{1-40}$ binding protein motif not easily realizable with smaller unstructured peptides. The results from this selection also correlate well with the previously described selections with both antibodies and peptides, where aromatic residue rich sequences are strongly favored. From a molecular perspective this may suggest a possible common binding mode for $A \beta$ where aromatic residues in suitable protein and peptide scaffolds interdigitate with an existing core $A \beta$ structure. In many of the above cases, experiments need to be performed to explore whether these $A \beta$ selected peptides and proteins also target multiple amyloidogenic proteins as observed in the case of the previously described antibodies.

\section{Targeting $A \beta$ with Small Molecules}

In the past decade numerous organic compounds have been studied for the inhibition of amyloid aggregation as a direct therapeutic strategy for the treatment of amyloidosis. These include surfactants, ${ }^{127} \mathrm{Cu} / \mathrm{Zn}$ chelators, ${ }^{128}$ known bioactive molecules (for example, apomorphine, ${ }^{129}$ rifamycine, ${ }^{130}$ curcumin, ${ }^{131}$ porphyrins, ${ }^{130}$ ), and sulfonated dyes such as Congo red and its derivatives. ${ }^{132}$ In fact, Congo red was the first small molecule reported to bind to amyloid in tissue sections and exhibited the characteristic yellow-green birefringence under cross polarizers. ${ }^{133,134}$ Later thioflavin T (ThT) and $\mathrm{S}$ (ThS) were also shown to characteristically stain amyloid deposits. ${ }^{135,} 136$ These two dyes are the classic reagents for determining characteristic $\beta$-sheet mediated fibrillization seen for all amyloid forming proteins. It speaks to the difficulty in the

* represents the atom radiolabeled. biophysical studies in this arena that the mode of interaction of these dyes with amyloid aggregates is still not clearly understood, though solid-state NMR studies may soon establish a molecular description of these interactions. Many reports indicate that these dyes selectively interdigitate between amyloid strands and it was believed that these dyes exclusively bind fibrils with $\beta$-sheet conformation. However, a report showed that Congo red could also form complexes with proteins having $\alpha$, $\alpha / \beta$ and $\beta$ conformations. ${ }^{137}$ Analogous studies with ThT, the reagent of choice for following $A \beta$ aggregation, need to be carried out as many reports on $A \beta$ inhibition are based on these assays. Congo red and ThT have also been shown to inhibit fibril formation ${ }^{42,138}$ at higher concentrations. Thus chemical derivatives of these dyes, with enhanced permeability through the blood-brain barrier, have been synthesized (Table 5) as in vivo imaging probes. ${ }^{139-141}$ Results from these ongoing studies may help in early diagnosis of AD.

Table 5. Chemical derivatives of Congo red and ThT used as imaging probes for detecting amyloid plaque.

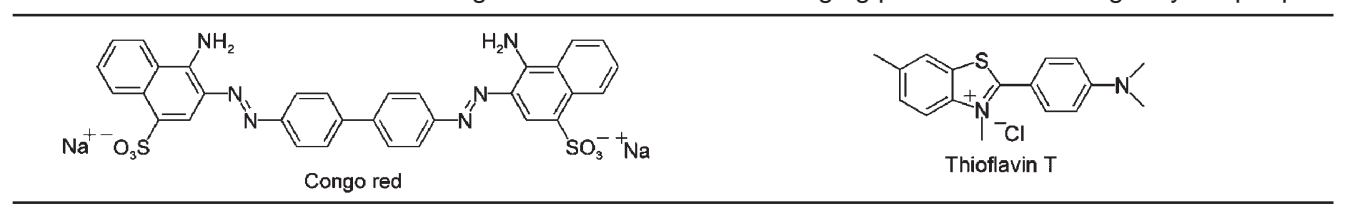

Fluorogenic and radiolabeled derivatives of Congo red and ThT
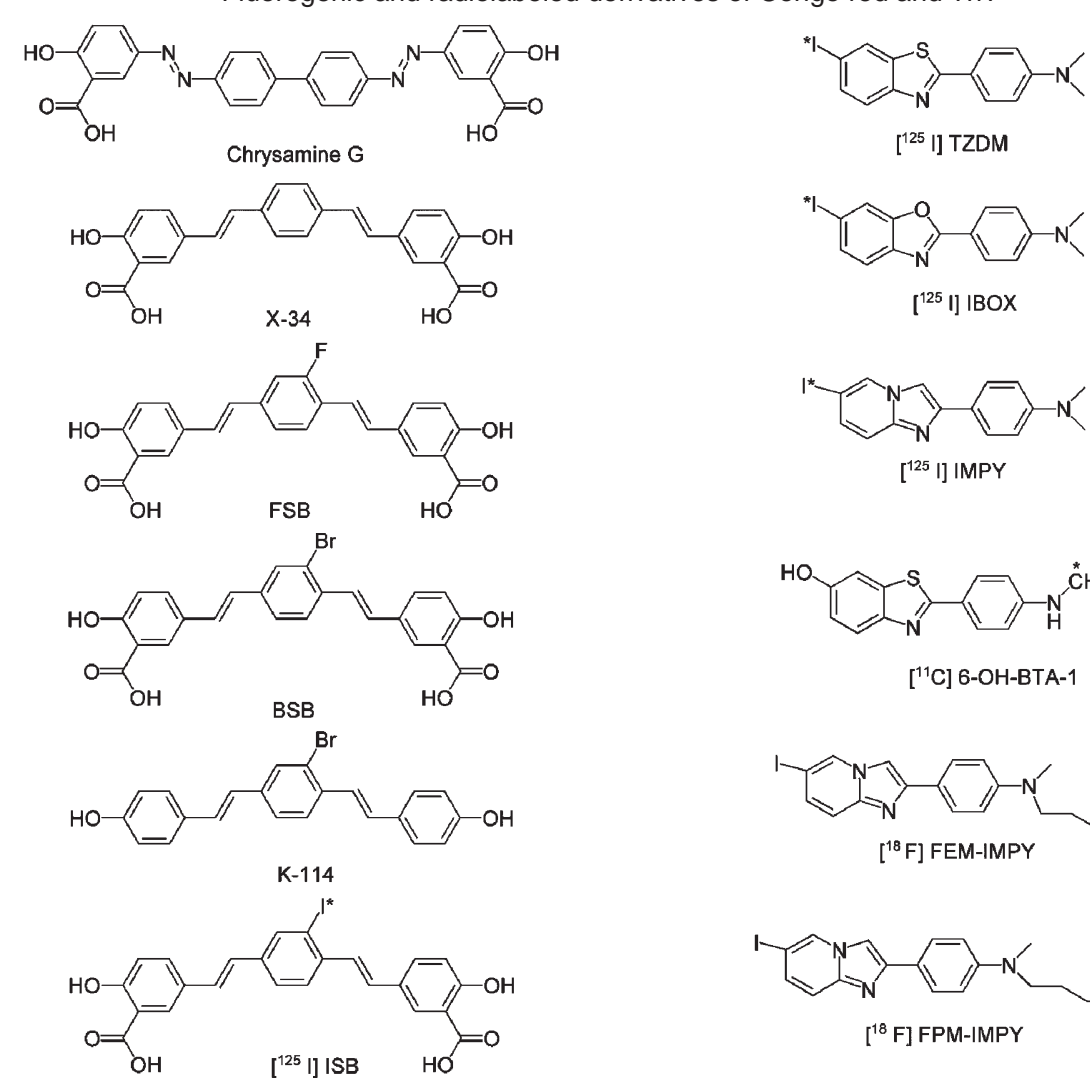

$[125$ I IMPY

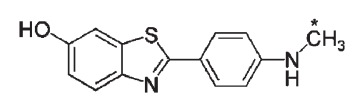

$\left[{ }^{11} \mathrm{C}\right]$ 6-OH-BTA-1

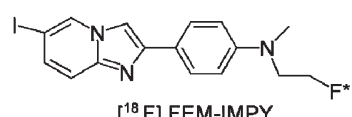

$\left[{ }^{18}\right.$ F] FEM-IMPY

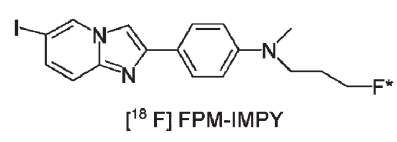


Not surprisingly perhaps, many reported small molecule inhibitors are similar to Congo Red and ThT, in that they are planar and aromatic. The possible mode of interaction with $A \beta$ has been reviewed by Porat et al. ${ }^{142}$ It is also interesting to again note that many of the proteins and peptides selected to bind $A \beta$ also contain a preponderance of aromatic residues. It is tempting to speculate that both small molecules and aromatic amino acid residues can intercalate within grooves created by $\beta$-sheets in both the soluble oligomeric forms as well as the large fibrils.

Many studies with small molecules have focused on the inhibition of fibril formation, however Blanchard et al. have screened a library of $>3000$ small molecules in an attempt to discover compounds that reduce the $\beta$-sheet content of preformed fibrils of $A \beta_{42}{ }^{143}$ Of the six lead compounds, 4,5-dianilinophthalimide (DAPH) was reported to effectively reduce $A \beta_{1-42}$ fibrils when incubated with preformed $A \beta_{1-42}$ fibrils in equimolar amounts for $24 \mathrm{~h}$. However, as is common to this field, the authors utilized the standard ThT assay in their screens, where there is the possibility of unintentionally isolating small molecules that interfere with ThT binding rather than disaggregate preformed amyloid fibers. Experiments have shown that many compounds (for example, melatonin, $\beta$-cyclodextrin, phthalocyanine, dimethyl yellow, and fenofibrate) competitively prevent the binding of ThT to the fibrils giving a possible false positive with regard to inhibition of $A \beta$ aggregation. ${ }^{42}$ However, elegant work by Lockhart et al. has shown that Congo red-type molecules do not share the same binding site as ThT on fibrils. ${ }^{146,147}$ Competition studies to determine the binding preferences of small molecule inhibitors and these classic ligands should be performed before conclusions regarding mechanisms of action are drawn.

With mounting evidence implicating soluble oligomeric intermediates as the toxic species, it is perhaps not sufficient to identify small molecule drug candidates that inhibit fibrillization but rather those that prevent toxicity. This is perhaps best exemplified by a study where naphthalene sulfonates were shown to inhibit fibril formation but stabilized the toxic oligomers. ${ }^{148}$ In another example, the hydroxyaniline derivatives, RS-0406 (reported to inhibit aggregation) ${ }^{149}$ and RS-0466 (reported to have no effect on aggregation) ${ }^{145}$ (Table 6) were shown to inhibit the formation of SDS-stable $A \beta$ oligomers in living cells. ${ }^{144}$

The most comprehensive effort in this area is a recent report by Glabe and co-workers, ${ }^{42}$ where they systematically evaluated 40 previously reported small molecule $A \beta$ inhibitors. This study attempts to clarify the role of the small molecule inhibitors in terms of their ability to interact with $A \beta$ oligomers or fibrils or both. A battery of assays were utilized, that included ThT fluorescence, turbidimetry, dot-blot/western blot assays with oligomer specific antibodies (A11), and TEM to understand the aggregation kinetics and minimize the effect of any artifact related to a particular assay. Based on their results, Necula et al. categorized their screens into three classes: class I consisted of compounds that inhibited oligomerization but not fibrillization, class II consisted of compounds that inhibited both oligomerization and fibrillization and class III were compounds that inhibited fibrillization and not oligomerization (Table 7). ${ }^{42}$

The data suggest that it may be possible to selectively inhibit "off-pathway" intermediates and/or fibril formation. This study agrees quite well with a screen of small molecules against tau filament formation and $\mathrm{A} \beta_{1-40}$ aggregation reported by Taniguchi et al. ${ }^{130} \mathrm{~A}$ comparison of the $\mathrm{IC}_{50}$ values reported by the two groups showed very similar trends in inhibitory activity and thus provides the field with a useful set of standard molecules (Figure 6). Interestingly, the A11 antibody is crossreactive with a wide variety of oligomeric species, ${ }^{118}$ indicating that inhibitors may have general applicability across many different aggregation diseases.

A clever approach combines small molecule targeting with natural bystander proteins to prevent amyloid aggregation. ${ }^{150}$ Gestwicki et al. designed a bifunctional molecule by covalently tethering a synthetic ligand (SLF) to Congo red (CR) (Figure 7 a). ${ }^{150} \mathrm{CR}$ at one end interacts with aggregated $A \beta$ whereas the synthetic ligand recruits a molecular chaperone (FKBP), providing the small molecule derivative with the necessary steric bulk to disrupt $A \beta$ aggregation. This approach significantly enhanced the potency of CR by several-fold $\left(\mathrm{IC}_{50}\right.$ of $C R, 2.9 \mu \mathrm{M}$; IC ${ }_{50}$ SLF-CR/FKBP, $\left.0.52 \mu \mathrm{M}\right)$. SLF-CR/FKBP

Table 6. Hydroxyaniline derivatives inhibited A $\beta$ oligomerization in APP-expressing $\mathrm{CHO}$ cells. ${ }^{144}$

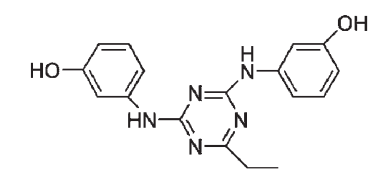

6-ethyl- $N, N^{\prime}$-bis(3-hydroxyphenyl)[1,3,5]triazine-2,4-diamine (RS-0466)

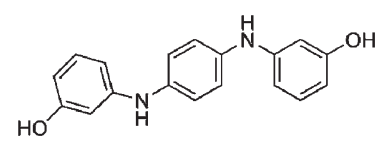

$N^{\prime}$-bis(3-hydroxyphenyl)pyridazine-3,6-diamine (RS-0406)

Comparison of results for RS-0466 and RS-0406

Nakagami et al. ${ }^{145}$

RS-0466 did not affect A $\beta$ fibrillization when measured by ThT assay, RS-0406 inhibited fibrillization, and also disassembled preformed $A \beta$ fibrils.

RS-0466 and RS-0406 inhibited A $\beta$ induced cytotoxicity in HeLa cells and blocked impairment of long-term potentiation in rat hippocampal slices.

How these compounds inhibited $A \beta$ induced cytotoxicity was not studied.
Walsh et al. ${ }^{144}$

These results were reproduced by Walsh et al. in their in vitro studies.

Both compounds prevented formation of $A \beta$ oligomers in living cells (7A2 cells) and blocked A $\beta$-mediated LTP.

It was shown that RS-0466 and RS-0406 inhibited the formation of new oligomers, they did not affect preformed $A \beta$ oligomers. 
Table 7. Small molecules categorized into classes based on their effect on $A \beta_{1-42}$ aggregation. ${ }^{42}$

Class I (Compounds that inhibit oligomerization but do not inhibit fibrillization)<smiles></smiles><smiles></smiles><smiles>COc1cc(-c2oc3cc(O)cc(O)c3c(=O)c2O)cc(O)c1O</smiles>

$\mathrm{HO}$<smiles>CCCN1CCN(CCCN2c3ccccc3Sc3ccc(Cl)cc32)CC1</smiles>

Perphenazine<smiles>COc1ccc2nc3cc(Cl)ccc3c(NC(C)CCCN(CCCl)CCCCl)c2c1</smiles>

Quinacrine mustard<smiles>CCCCCCCCCCCCCCCCCCCCCCCCC</smiles>

Class II (Compounds that inhibit both oligomerization and fibrillization)<smiles></smiles>

Rhodamine B<smiles></smiles><smiles>CC(Cc1ccc(O)c(O)c1)C(C)Cc1ccc(O)c(O)c1</smiles><smiles>COc1cc(/C=C/C(=O)CC(=O)/C=C/c2ccc(O)c(OC)c2)ccc1O</smiles>

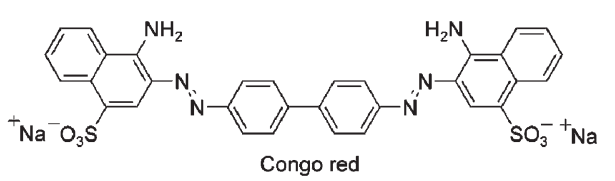<smiles>CCN(CCO)c1ccc(N=Nc2sc3cc(OC)ccc3[n+]2C)cc1</smiles>
Basic blue 41<smiles>Cc1ccc2c(c1)sc(-c1ccc(N(C)C)cc1)[n+]2[O-]</smiles><smiles></smiles>

Tetradecyl trimethyl ammonium bromide Class $\mid \geq 300 \mu \mathrm{M}$<smiles>CN1CCc2cccc3c2C1Cc1ccc(O)c(O)c1-3</smiles>

Apomorphine<smiles>O=C1C=CC(=O)c2c(O)cccc21</smiles><smiles></smiles><smiles>COc1cccc2c1C(=O)c1c(O)c3c(c(O)c1C2=O)C[C@@](O)(C(C)=O)C[C@H]3O[C@H]1C[C@H](N)[C@@H](O)[C@H](C)O1</smiles>

Daunomycin

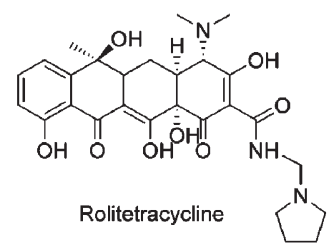<smiles>O=C(c1ccccc1O)c1ccccc1O</smiles>

2,2'-Dihydroxy benzophenone

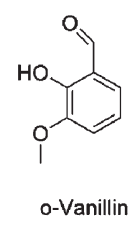

o-Vanillin 
Table 7. Small molecules categorized into classes based on their effect on $A \beta_{1-42}$ aggregation ${ }^{42}$ (continued).
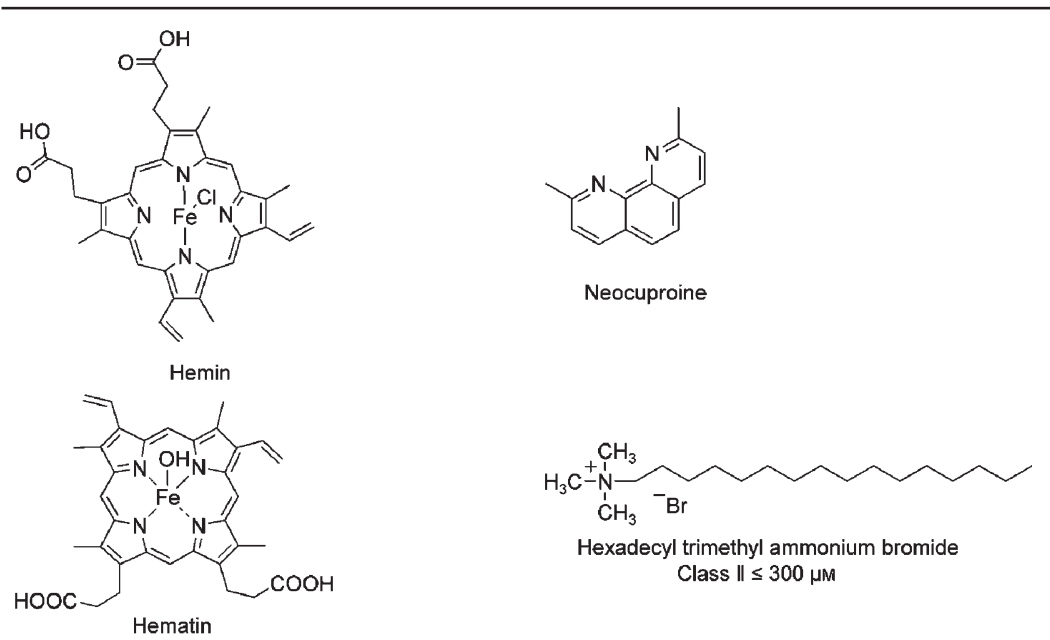
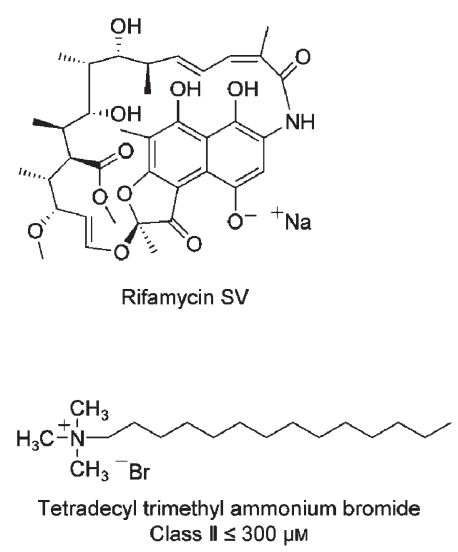

Class III (Compounds that inhibit fibrillization but do not inhibit oligomerization)
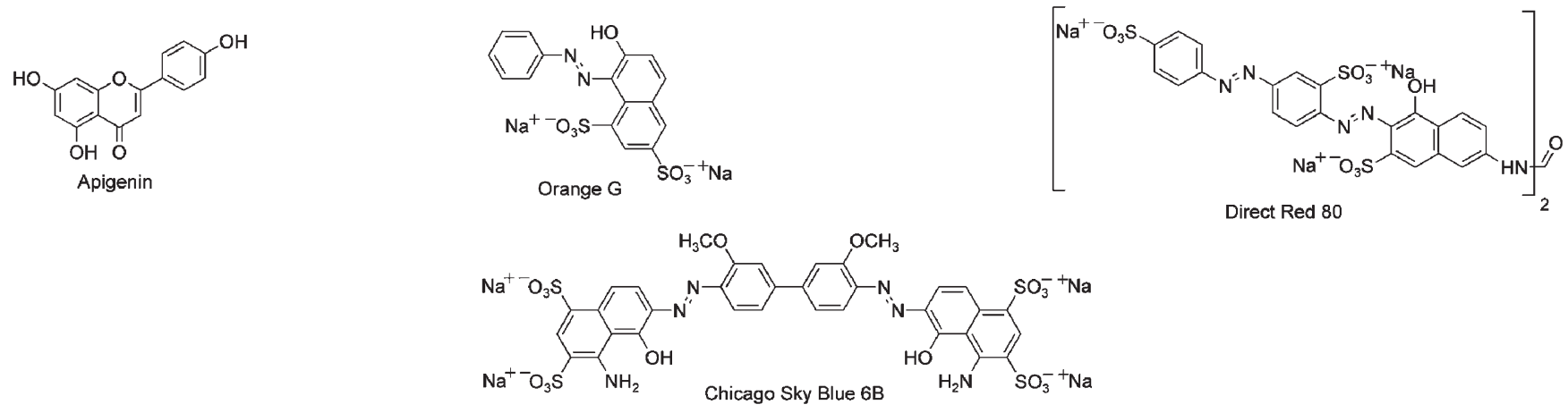

treated neurons displayed normal morphology and high cell viability $(\sim 70 \%)$. To further increase the potency of the bivalent inhibitor, the authors varied the linker length between SLF and CR. Of the three new molecules created (Figure $7 \mathrm{~b}$ ), SLFBenz-CR/FKBP was most effective with an $\mathrm{IC}_{50}$ of $50 \mathrm{nM}$. The authors did observe the presence of small aggregates in electrophoretic analysis and AFM images in $A \beta$ samples treated with their bifunctional molecule.

Finally a screen has been developed for the discovery of $A \beta$ aggregation inhibitors in $E$. coli cells. ${ }^{151}$ This approach takes advantage of a green fluorescent protein (GFP) based assay ${ }^{152}$ where the fluorescence of GFP is compromised by attachment of $A \beta$, presumably due to GFP-misfolding mediated by $A \beta$ aggregation. GFP folding and fluorescence is recovered upon treatment of the $E$. coli with small molecules that likely disrupt $A \beta$ aggregation. This may be a useful approach for the rapid screening of small molecule $A \beta$ inhibitors and could eventually be used in more permeable mammalian cells.

Overall, the small molecule approach to $A \beta$ aggregation inhibition is clearly poised to provide new and useful reagents for in vivo diagnostics as therapeutic applications are already being demonstrated for analogues of classic $A \beta$ binders such as Congo Red and ThT. The existing small molecules are also being probed for their ability to interact with different amyloid species along the fibrillization pathway, which when correlated with cellular toxicity studies will likely provide useful protocols for evaluating new anti-A $\beta$ molecules as they are identified.

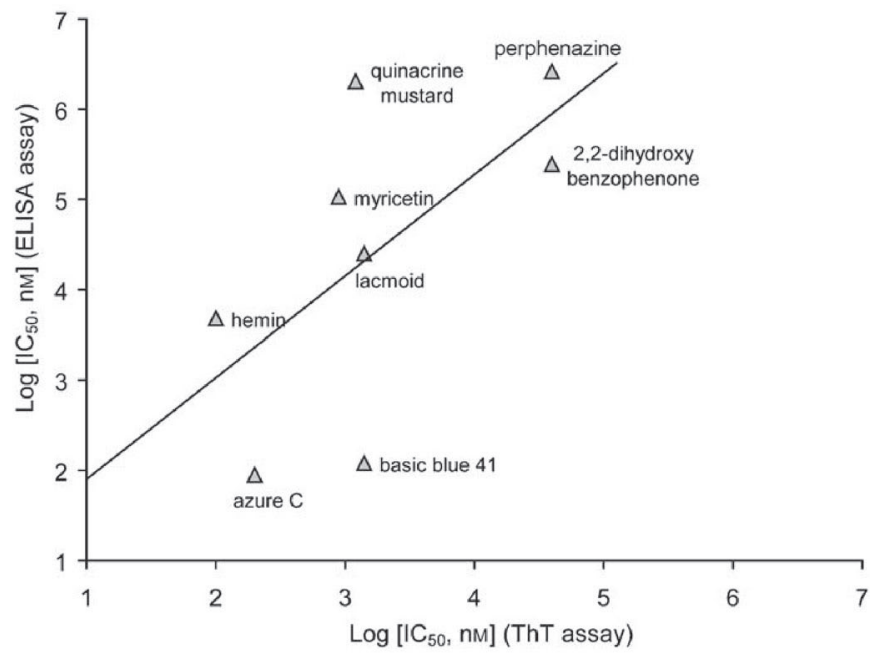

Figure 6. A comparison of the $I_{50}$ values reported by Taniguchi et al. ${ }^{130}$ and Necula et al. ${ }^{42}$ for the inhibition of $A \beta$ aggregation by small molecules. 
a)

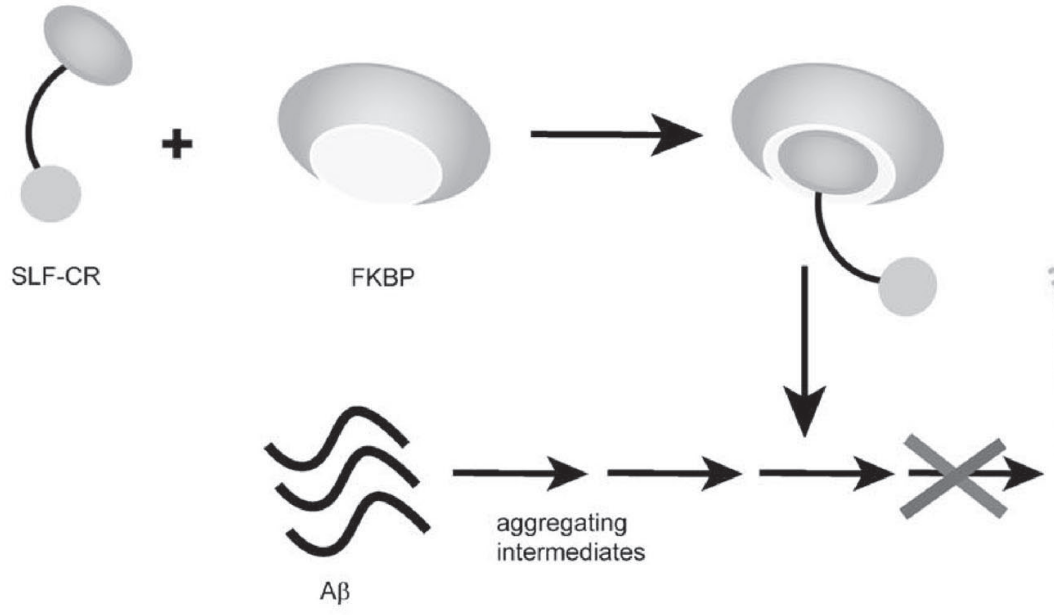

b)

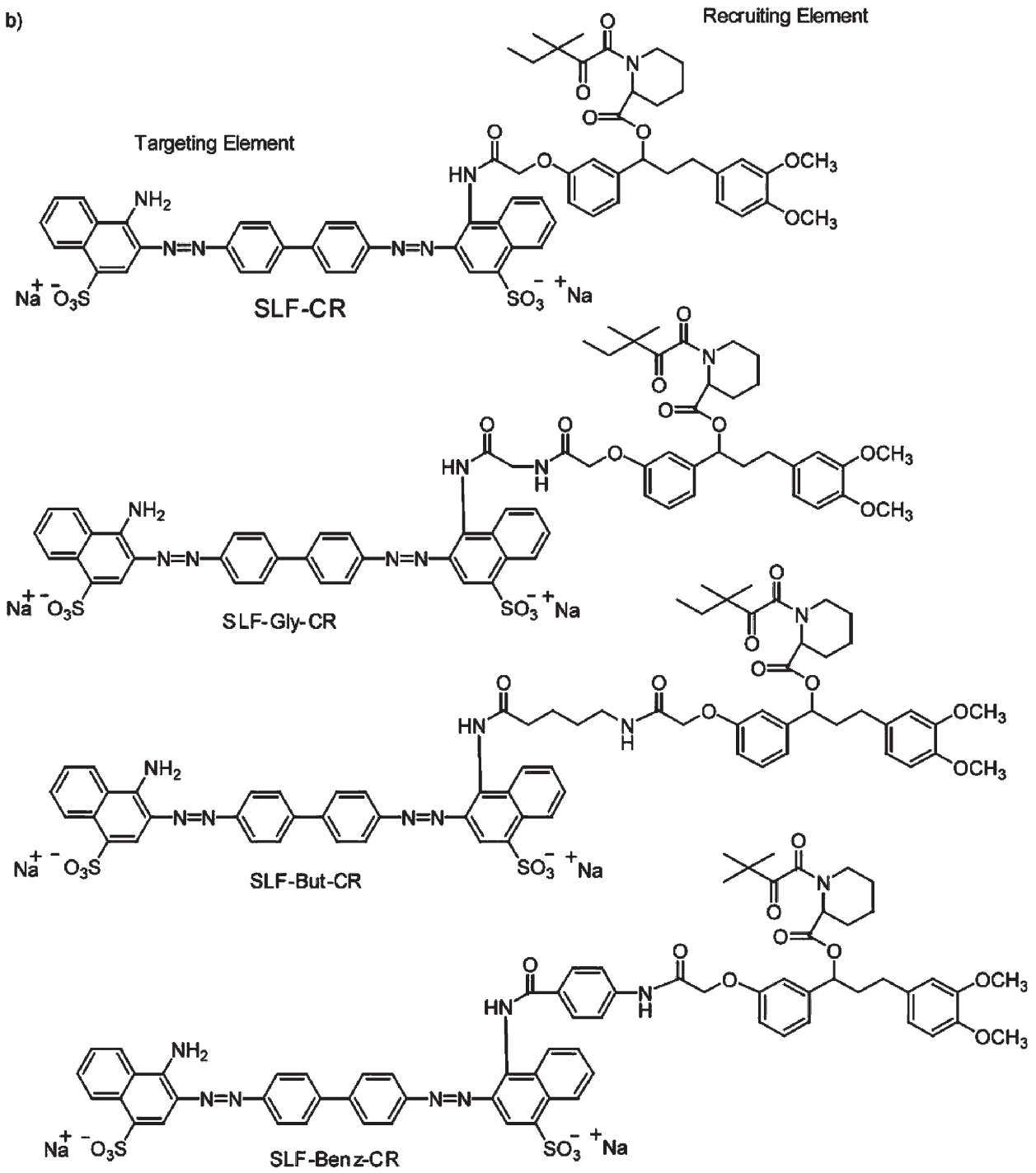

Figure 7. a) Blocking $A \beta$ fibrillization using a bifunctional small molecule that binds to FKBP to increase the steric bulk of the molecule. b) Adding linkers into SLF-CR improves inhibition of aggregation and toxicity.

\section{Summary}

In this review we have aimed to provide a comprehensive view of the rapidly growing molecular toolbox at our disposal for targeting $A \beta$. We have described a wide range of molecules that target $A \beta$, including natural proteins, peptides, peptidomimetics, and small molecules. We have also described recent approaches for selections and screens for developing $A \beta$ targeting antibodies, proteins, and peptides that have been shown to interact with $A \beta$ oligomers and fibrils and influence aggregation kinetics. These new strategies and the resulting molecules being discovered provide a starting point for analogue synthesis that should help in furthering our understanding of the mechanism of $A \beta$ aggregation and ultimately aid in reducing cellular toxicity. Moreover, many of these new approaches may be applied to other amyloidogenic diseases. These molecules provide new and interesting design opportunities as seen in the case of the novel small molecule directed chaperones. Opportunities clearly exist for utilizing the described small molecules and peptides discovered to date for decorating discrete multivalent dendrimers to provide new multivalent entities for targeting both oligomers and fibrils. ${ }^{93}, 153,154$ Thus with this growing toolbox in hand, new methods for the molecular design of diagnostic and therapeutic agents will clearly be forthcoming.

\section{Outlook}

The study of the aggregation pathway of $A \beta$ is a difficult and challenging endeavor and future work in targeting $A \beta$ will necessitate the development of sensitive analytical methods that continue to clarify molecular mechanisms for the pathophysiology of Alzheimer's disease. Furthermore, new biophysical studies must aim to correlate 
in vivo toxicity with in vitro aggregation models to allow for accurate interpretation of the mechanism of action of the molecules that are currently available. From a molecular design perspective, the many ligands that we have described should be amenable to further chemical functionalization with appropriate imaging agents to develop new and powerful in vitro and in vivo assays that target different species in the fibrillization pathway. This approach will allow for the development of molecules that target specific $A \beta$ assemblies and correlate them to disease outcomes. As an example, many of the reported small molecules that target oligomers and fibrils, will likely be amenable to radioisotope incorporation for in vivo diagnostic imaging with PET (Positron Emission Tomography) ${ }^{155}$ and SPECT (Single Photon Emission Computerized Tomography). ${ }^{139,} 156$ Thus at the current time we are clearly at the threshold of discovering new diagnostic tools as well as therapeutic molecules that may help ameliorate the devastating neurological effects of Alzheimer's disease.

\section{Acknowledgments}

We thank T. J. Smith for initiating this project. We thank the ABRC and the NIH (R21AG025954 and R01Al68414) for support.

\section{References}

[1] M. E. Huff, W. E. Balch, J. W. Kelly, Curr. Opin. Struct. Biol. 2003, 13, 674- 682 .

[2] D. M. Walsh, D. J. Selkoe, Protein Pept. Lett. 2004, 11, 213-228.

[3] D. J. Selkoe, Nat. Cell Biol. 2004, 6, 1054- 1061.

[4] E. H. Koo, P. T. Lansbury, J. W. Kelly, Proc. Natl. Acad. Sci. USA 1999, 96, 9989-9990.

[5] P. C. Fraering, W. J. Ye, J. M. Strub, G. Dolios, M. J. LaVoie, B. L. Ostaszewski, A. van Dorsselaer, R. Wang, D. J. Selkoe, M. S. Wolfe, Biochemistry 2004, 43, 9774-9789.

[6] W. T. Kimberly, W. P. Esler, W. J. Ye, B. L. Ostaszewski, J. Gao, T. Diehl, D. J. Selkoe, M. S. Wolfe, Biochemistry 2003, 42, 137- 144.

[7] D. J. Selkoe, D. Schenk, Annu. Rev. Pharmacol. Toxicol. 2003, 43, 545- 584.

[8] A. Lorenzo, M. L. Yuan, Z. H. Zhang, P. A. Paganetti, C. SturchlerPierrat, M. Staufenbiel, J. Mautino, F. Sol Vigo, B. Sommer, B. A. Yankner, Nat. Neurosci. 2000, 3, 460-464.

[9] Y. Matsuoka, A. J. Gray, C. Hirata-Fukae, S. S. Minami, E. G. Waterhouse, M. P. Mattson, F. M. LaFerla, I. Gozes, P. S. Aisen, J. Mol. Neurosci. 2007, 31, 165-170.

[10] S. Miranda, C. Opazo, L. F. Larrondo, F. J. Munoz, F. Ruiz, F. Leighton, N. C. Inestrosa, Prog. Neurobiol. 2000, 62, 633- 648.

[11] D. A. Butterfield, J. Drake, C. Pocernich, A. Castegna, Trends Mol. Med. 2001, 7, 548- 554 .

[12] A. J. Tenner, Neurobiol. Aging 2001, 22, 849-861.

[13] J. Hardy, D. J. Selkoe, Science 2002, 297, 353- 356.

[14] J. C. Rochet, P. T. Lansbury, Curr. Opin. Struct. Biol. 2000, 10, 60-68.

[15] D. M. Walsh, A. Lomakin, G. B. Benedek, M. M. Condron, D. B. Teplow, J. Biol. Chem. 1997, 272, 22364-22372.

[16] C. M. Dobson, Nature 2003, 426, 884- 890.

[17] M. Bucciantini, E. Giannoni, F. Chiti, F. Baroni, L. Formigli, J. S. Zurdo, N. Taddei, G. Ramponi, C. M. Dobson, M. Stefani, Nature 2002, 416, 507- 511.

[18] F. E. Cohen, S. B. Prusiner, Annu. Rev. Biochem. 1998, 67, 793- 819 .

[19] J. D. Harper, S. S. Wong, C. M. Lieber, P. T. Lansbury, Chem. Biol. 1997, 4, 119-125.
[20] K. N. Dahlgren, A. M. Manelli, W. B. Stine, L. K. Baker, G. A. Krafft, M. J. LaDu, J. Biol. Chem. 2002, 277, 32046-32053.

[21] D. M. Walsh, I. Klyubin, J. V. Fadeeva, W. K. Cullen, R. Anwyl, M. S. Wolfe, M. J. Rowan, D. J. Selkoe, Nature 2002, 416, 535- 539.

[22] D. M. Hartley, D. M. Walsh, C. P. P. Ye, T. Diehl, S. Vasquez, P. M. Vassilev, D. B. Teplow, D. J. Selkoe, J. Neurosci. 1999, 19, 8876-8884.

[23] M. P. Lambert, A. K. Barlow, B. A. Chromy, C. Edwards, R. Freed, M. Liosatos, T. E. Morgan, I. Rozovsky, B. Trommer, K. L. Viola, P. Wals, C. Zhang, C. E. Finch, G. A. Krafft, W. L. Klein, Proc. Natl. Acad. Sci. USA 1998, 95, 6448-6453.

[24] C. J. Pike, A. J. Walencewicz, C. G. Glabe, C. W. Cotman, Brain Res. 1991, 563, 311-314.

[25] C. J. Pike, A. J. Walencewicz, C. G. Glabe, C. W. Cotman, Eur. J. Pharmacol. 1991, 207, 367-368.

[26] M. S. Shearman, C. I. Ragan, L. L. Iversen, Proc. Natl. Acad. Sci. USA 1994, 91, 1470-1474.

[27] C. A. Lemere, J. K. Blusztajn, H. Yamaguchi, T. Wisniewski, T. C. Saido, D. J. Selkoe, Neurobiol. Dis. 1996, 3, 16-32.

[28] C. A. McLean, R. A. Cherny, F. W. Fraser, S. J. Fuller, M. J. Smith, K. Beyreuther, A. I. Bush, C. L. Masters, Ann. Neurol. 1999, 46, 860- 866 .

[29] J. Naslund, V. Haroutunian, R. Mohs, K. L. Davis, P. Davies, P. Greengard, J. D. Buxbaum, JAMA J. Am. Med. Assoc. 2000, 283, 1571-1577.

[30] R. D. Terry, E. Masliah, D. P. Salmon, N. Butters, R. Deteresa, R. Hill, L. A. Hansen, R. Katzman, Ann. Neurol. 1991, 30, 572-580.

[31] D. H. Chui, H. Tanahashi, K. Ozawa, S. Ikeda, F. Checler, O. Ueda, H. Suzuki, W. Araki, H. Inoue, K. Shirotani, K. Takahashi, F. Gallyas, T. Tabira, Nat. Med. 1999, 5, 560-564.

[32] A. Y. Hsia, E. Masliah, L. McConlogue, G. Q. Yu, G. Tatsuno, K. $\mathrm{Hu}$, D. Kholodenko, R. C. Malenka, R. A. Nicoll, L. Mucke, Proc. Natl. Acad. Sci. USA 1999, 96, 3228- 3233.

[33] Y. S. Gong, L. Chang, K. L. Viola, P. N. Lacor, M. P. Lambert, C. E. Finch, G. A. Krafft, W. L. Klein, Proc. Natl. Acad. Sci. USA 2003, 100, 10417- 10422.

[34] M. Hoshi, M. Sato, S. Matsumoto, A. Noguchi, K. Yasutake, N. Yoshida, K. Sato, Proc. Natl. Acad. Sci. USA 2003, 100, 6370-6375.

[35] I. Klyubin, D. M. Walsh, C. A. Lemere, W. K. Cullen, G. M. Shankar, V. Betts, E. T. Spooner, L. Y. Jiang, R. Anwyl, D. J. Selkoe, M. J. Rowan, Nat. Med. 2005, 11, 556-561.

[36] C. Haass, D. J. Selkoe, Nat. Rev. Mol. Cell Biol. 2007, 8, 101-112.

[37] M. Arrasate, S. Mitra, E. S. Schweitzer, M. R. Segal, S. Fink beiner, Nature 2004, 431, 805-810.

[38] G. Schaffar, P. Breuer, R. Boteva, C. Behrends, N. Tzvetkov, N. Strippel, H. Sakahira, K. Siegers, M. Hayer-Hartl, F. U. Hartl, Mol. Cell 2004, 15, 95- 105.

[39] A. B. Bowman, S. Y. Yoo, N. P. Dantuma, H. Y. Zoghbi, Hum. Mol. Genet. 2005, 14, 679-691.

[40] J. R. Gatchel, H. Y. Zoghbi, Nat. Rev. Genet. 2005, 6, 743-755.

[41] J. Tsai, J. Grutzendler, K. Duff, W. B. Gan, Nat. Neurosci. 2004, 7 , $1181-1183$

[42] M. Necula, R. Kayed, S. Milton, C. G. Glabe, J. Biol. Chem. 2007, 282, 10311-10324.

[43] L. G. Alonso, M. M. Garcia-Alai, C. Smal, J. M. Centeno, R. Iacono, E. Castano, P. Gualfetti, G. de Prat-Gay, Biochemistry 2004, 43, 3310-3317.

[44] D. A. Haley, J. Horwitz, P. L. Stewart, J. Mol. Biol. 1998, 277, 27-35.

[45] S. C. Meyer, C. Huerta, I. Ghosh, Biochemistry 2005, 44, 2360-2368.

[46] J. Moradian-Oldak, M. L. Paine, Y. P. Lei, A. G. Fincham, M. L. Snead, J. Struct. Biol. 2000, 131, 27-37. 
[47] M. Ramirez-Alvarado, J. S. Merkel, L. Regan, Proc. Natl. Acad. Sci. USA 2000, 97, 8979-8984.

[48] A. T. Petkova, W. M. Yau, R. Tycko, Biochemistry 2006, 45, 498- 512.

[49] R. Tycko, Q. Rev. Biophys. 2006, 39, 1-55.

[50] K. L. Sciarretta, D. J. Gordon, A. T. Petkova, R. Tycko, S. C. Meredith, Biochemistry 2005, 44, 6003-6014.

[51] N. W. Schiffer, S. A. Broadley, T. Hirschberger, P. Tavan, H. A. Kretzschmar, A. Giese, C. Haass, F. U. Hartl, B. Schmid, J. Biol. Chem. 2007, 282, 9195-9203.

[52] M. B. Podlisny, B. L. Ostaszewski, S. L. Squazzo, E. H. Koo, R. E. Rydell, D. B. Teplow, D. J. Selkoe, J. Biol. Chem. 1995, 270, 9564- 9570.

[53] D. M. Walsh, B. P. Tseng, R. E. Rydel, M. B. Podlisny, D. J. Selkoe, Biochemistry 2000, 39, 10831-10839.

[54] H. A. Lashuel, D. Hartley, B. M. Petre, T. Walz, P. T. Lansbury, Nature 2002, 418, 291- 291.

[55] G. Bitan, M. D. Kirkitadze, A. Lomakin, S. S. Vollers, G. B. Benedek, D. B. Teplow, Proc. Natl. Acad. Sci. USA 2003, 100, 330-335.

[56] S. LesnQ, M. T. Koh, L. Kotilinek, R. Kayed, C. G. Glabe, A. Yang, M. Gallagher, K. H. Ashe, Nature 2006, 440, 352-357.

[57] S. R. Hughes, S. Goyal, J. E. Sun, P. Gonzalez-DeWhitt, M. A. Fortes, N. G. Riedel, S. R. Sahasrabudhe, Proc. Natl. Acad. Sci. USA 1996, 93, 2065- 2070.

[58] S. Du Yan, J. Fu, C. Soto, X. Chen, H. J. Zhu, F. Al-Mohanna, K. Collison, A. P. Zhu, E. Stern, T. Saido, M. Tohyama, S. Ogawa, A. Roher, D. Stern, Nature 1997, 389, 689-695.

[59] J. W. Lustbader, M. Cirilli, C. Lin, H. W. Xu, K. Takuma, N. Wang, C. Caspersen, X. Chen, S. Pollak, M. Chaney, F. Trinchese, S. M. Liu, F. Gunn- Moore, L. F. Lue, D. G. Walker, P. Kuppusamy, Z. L. Zewier, O. Arancio, D. Stern, S. S. D. Yan, H. Wu, Science 2004, 304, 448-452.

[60] Y. L. Xie, S. M. Deng, Z. Z. Chen, S. D. Yan, D. W. Landry, Bioorg. Med. Chem. Lett. 2006, 16, 4657- 4660.

[61] A. Chauhan, V. P. S. Chauhan, N. Murakami, H. Brockerhoff, H. M. Wisniewski, Brain Res. 1993, 629, 47-52.

[62] M. K. Lakshmana, W. Araki, T. Tabira, FASEB J. 2005, 19, 1362- 1364.

[63] M. Bassan, R. Zamostiano, A. Davidson, A. Pinhasov, E. Giladi, O. Perl, H. Bassan, C. Blat, G. Gibney, G. Glazner, D. E. Brenneman, I. Gozes, J. Neurochem. 1999, 72, 1283-1293.

[64] C. R. Abraham, D. J. Selkoe, H. Potter, Cell 1988, 52, 487-501.

[65] H. Y. Wang, D. H. S. Lee, M. R. D'Andrea, P. A. Peterson, R. P. Shank, A. B. Reitz, J. Biol. Chem. 2000, 275, 5626-5632.

[66] C. S. Casley, L. Canevari, J. M. Land, J. B. Clark, M. A. Sharpe, J. Neurochem. 2002, 80, 91-100.

[67] S. R. Hughes, O. Khorkova, S. Goyal, J. Knaeblein, J. Heroux, N. G. Riedel, S. Sahasrabudhe, Proc. Natl. Acad. Sci. USA 1998, 95, 3275- 3280.

[68] R. W. Mahley, K. H. Weisgraber, Y. D. Huang, Proc. Natl. Acad. Sci. USA 2006, 103, 5644-5651.

[69] K. R. Bales, T. Verina, D. J. Cummins, Y. S. Du, T. C. Dodel, J. Saura, C. E. Fishman, C. A. DeLong, P. Piccardo, V. Petegnief, B. Ghetti, S. M. Paul, Proc. Natl. Acad. Sci. USA 1999, 96, 15233- 15238.

[70] J. Ghiso, E. Matsubara, A. Koudinov, N. H. Choimiura, M. Tomita, T. Wisniewski, B. Frangione, Biochem. J. 1993, 293, 27-30.

[71] N. G. N. Milton, Biochem. J. 1999, 344, 293-296.

[72] T. Hashimoto, T. Wakabayashi, A. Watanabe, H. Kowa, R. Hosoda, A. Nakamura, I. Kanazawa, T. Arai, K. Takio, D. M. A. Mann, T. Iwatsubo, EMBO J. 2002, 21, 1524-1534.

[73] Y. Y. Le, W. H. Gong, H. L. Tiffany, A. Tumanov, S. Nedospasov, W. P. Shen, N. M. Dunlop, J. L. Gao, P. M. Murphy, J. J. Oppenheim, J. M. Wang, J. Neurosci. 2001, 21, RC123.
[74] V. P. S. Chauhan, I. Ray, A. Chauhan, H. M. Wisniewski, Biochem. Biophys. Res. Commun. 1999, 258, 241- 246.

[75] C. G. Evans, S. Wisen, J. E. Gestwicki, J. Biol. Chem. 2006, 281, 33182- 33191.

[76] L. Xie, E. Helmerhorst, K. Taddei, B. Plewright, W. van Bronswijk, R. Martins, J. Neurosci. 2002, 22, RC221.

[77] S. Sabo, M. P. Lambert, K. Kessey, W. Wade, G. Krafft, W. L. Klein, Neurosci. Lett. 1995, 184, 25- 28.

[78] X. Bi, C. M. Gall, J. Zhou, G. Lynch, Neuroscience 2002, 112, 827-840.

[79] M. Yaar, S. Zhai, P. F. Pilch, S. M. Doyle, P. B. Eisenhauer, R. E. Fine, B. A. Gilchrest, J. Clin. Invest. 1997, 100, 2333-2340.

[80] Y. Luo, D. B. Hawver, K. Iwasaki, T. Sunderland, G. S. Roth, B. Wolozin, Brain Res. 1997, 769, 287- 295.

[81] S. D. Yan, X. Chen, J. Fu, M. Chen, H. J. Zhu, A. Roher, T. Slattery, L. Zhao, M. Nagashima, J. Morser, A. Migheli, P. Nawroth, D. Stern, A. M. Schmidt, Nature 1996, 382, 685-691.

[82] D. M. Paresce, R. N. Ghosh, F. R. Maxfield, Neuron 1996, 17, 553-565.

[83] G. Joslin, J. E. Krause, A. D. Hershey, S. P. Adams, R. J. Fallon, D. H. Perlmutter, J. Biol. Chem. 1991, 266, 21897-21902.

[84] K. S. Kosik, C. L. Joachim, D. J. Selkoe, Proc. Natl. Acad. Sci. USA 1986, 83, 4044- 4048.

[85] A. L. Schwarzman, L. Gregori, M. P. Vitek, S. Lyubski, W. J. Strittmatter, J. J. Enghilde, R. Bhasin, J. Silverman, K. H. Weisgraber, P. K. Coyle, M. G. Zagorski, J. Talafous, M. Eisenberg, A. M. Saunders, A. D. Roses, D. Goldgaber, Proc. Natl. Acad. Sci. USA 1994, 91, 8368- 8372.

[86] M. Flajolet, G. He, M. Heiman, A. Lin, A. C. Nairn, P. Greengard, Proc. Natl. Acad. Sci. USA 2007, 104, 4159-4164.

[87] I. Zemlyak, S. Furman, D. E. Brenneman, I. Gozes, Regul. Pept 2000, 96, 39- 43.

[88] T. D. Stein, J. A. Johnson, J. Neurosci. 2002, 22, 7380-7388.

[89] A. L. Schwarzman, M. Tsiper, H. Wente, A. Wang, M. P. Vitek, V. Vasiliev, D. Goldgaber, Amyloid 2004, 11, 1-9.

[90] L. Liu, R. M. Murphy, Biochemistry 2006, 45, 15702-15709.

[91] S. M. Johnson, R. L. Wiseman, Y. Sekijima, N. S. Green, S. L. Adamski- Werner, J. W. Kelly, Acc. Chem. Res. 2005, 38, 911- 921.

[92] L. O. Tjernberg, J. Naslund, F. Lindqvist, J. Johansson, A. R. Karlstrom, J. Thyberg, L. Terenius, C. Nordstedt, J. Biol. Chem. 1996, 271, 8545- 8548.

[93] T. L. Lowe, A. Strzelec, L. L. Kiessling, R. M. Murphy, Biochemistry 2001, 40, 7882- 7889.

[94] C. W. Cairo, A. Strzelec, R. M. Murphy, L. L. Kiessling, Biochemistry 2002, 41, 8620-8629.

[95] L. Fulop, M. Zarandi, Z. Datki, K. Soos, B. Penke, Biochem. Biophys. Res. Commun. 2004, 324, 64-69.

[96] C. Soto, E. M. Sigurdsson, L. Morelli, R. A. Kumar, E. M. Castano, B. Frangione, Nat. Med. 1998, 4, 822-826.

[97] M. A. Etienne, J. P. Aucoin, Y. W. Fu, R. L. McCarley, R. P. Hammer, J. Am. Chem. Soc. 2006, 128, 3522-3523.

[98] D. J. Gordon, K. L. Sciarretta, S. C. Meredith, Biochemistry 2001, 40, 8237-8245.

[99] E. Hughes, R. M. Burke, A. J. Doig, J. Biol. Chem. 2000, 275, 25109- 25115.

[100] D. J. Gordon, S. C. Meredith, Biochemistry 2003, 42, 475-485.

[101] K. Watanabe, K. Nakamura, S. Akikusa, T. Okada, M. Kodaka, T. Konakahara, H. Okuno, Biochem. Biophys. Res. Commun. 2002, 290, 121-124.

[102] N. Kokkoni, K. Stott, H. Amijee, J. M. Mason, A. J. Doig, Biochemistry 2006, 45, 9906-9918.

[103] R. J. Chalifour, R. W. McLaughlin, L. Lavoie, C. Morissette, N. Tremblay, M. Boule, P. Sarazin, D. Stea, D. Lacombe, P. Tremblay, F. Gervais, J. Biol. Chem. 2003, 278, 34874- 34881. 
[104] M. A. Findeis, G. M. Musso, C. C. Arico-Muendel, H. W. Benjamin, A. M. Hundal, J. J. Lee, J. Chin, M. Kelley, J. Wakefield, N. J. Hayward, S. M. Molineaux, Biochemistry 1999, 38, 6791-6800.

[105] T. Sato, P. Kienlen-Campard, M. Ahmed, W. Liu, H. L. Li, J. I. Elliott, S. Aimoto, S. N. Constantinescu, J. N. Octave, S. O. Smith, Biochemistry 2006, 45, 5503-5516.

[106] J. R. Kim, T. J. Gibson, R. M. Murphy, J. Biol. Chem. 2003, 278, 40730- 40735.

[107] J. M. Mason, N. Kokkoni, K. Stott, A. J. Doig, Curr. Opin. Struct. Biol. 2003, 13, 526-532.

[108] H. L. Weiner, C. A. Lemere, R. Maron, E. T. Spooner, T. J. Grenfell, C. Mori, S. Issazdeh, W. W. Hancock, D. J. Selkoe, Ann. Neurol. 2000, 48, 567-579.

[109] K. Birmingham, S. Frantz, Nat. Med. 2002, 8, 199-200.

[110] J. M. Orgogozo, S. Gilman, J. F. Dartigues, B. Laurent, M. Puel, L. C. Kirby, P. Jouanny, B. Dubois, L. Eisner, S. Flitman, B. F. Michel, M. Boada, A. Frank, C. Hock, Neurology 2003, 61, 46-54.

[111] M. Lee, F. Bard, K. Johnson-Wood, C. Lee, K. Hu, S. G. Griffith, R. S. Black, D. Schenk, P. Seubert, Ann. Neurol. 2005, 58, 430- 435 .

[112] T. Town, J. Tan, N. Sansone, D. Obregon, T. Klein, M. Mullan, Neurosci. Lett. 2001, 307, 101-104.

[113] M. G. Agadjanyan, A. Ghochikyan, I. Petrushina, V. Vasilevko, N. Movsesyan, M. Mkrtichyan, T. Saing, D. H. Cribbs, J. Immunol. 2005, 174, 1580- 1586.

[114] N. Moretto, A. Bolchi, C. Rivetti, B. P. Imbimbo, G. Villetti, V. Pietrini, L. Polonelli, S. D. Signore, K. M. Smith, R. J. Ferrante, S. Ottonello, J. Biol. Chem. 2007, 282, 11436-11445.

[115] M. Maier, T. J. Seabrook, N. D. Lazo, L. Y. Jiang, P. Das, C. Janus, C. A. Lemere, J. Neurosci. 2006, 26, 4717-4728.

[116] B. O'Nuallain, R. Wetzel, Proc. Natl. Acad. Sci. USA 2002, 99, 1485- 1490.

[117] M. P. Lambert, K. L. Viola, B. A. Chromy, L. Chang, T. E. Morgan, J. X. Yu, D. L. Venton, G. A. Krafft, C. E. Finch, W. L. Klein, J. Neurochem. 2001, 79, 595- 605.

[118] R. Kayed, E. Head, J. L. Thompson, T. M. McIntire, S. C. Milton, C. W. Cotman, C. G. Glabe, Science 2003, 300, 486-489.

[119] H. K. Binz, A. Pluckthun, Curr. Opin. Biotechnol. 2005, 16, 459- 469.

[120] S. Rajagopal, R. Meza-Romero, I. Ghosh, Bioorg. Med. Chem. Lett. 2004, 14, 1389- 1393.

[121] C. K. Kang, V. Jayasinha, P. T. Martin, Neurobiol. Dis. 2003, 14, 146-156.

[122] K. Wiesehan, K. Buder, R. P. Linke, S. Patt, M. Stoldt, E. Unger, B. Schmitt, E. Bucci, D. Willbold, ChemBioChem 2003, 4, 748- 753 .

[123] B. P. Orner, L. Liu, R. M. Murphy, L. L. Kiessling, J. Am. Chem. Soc. 2006, 128, 11882- 11889.

[124] T. J. Smith, C. I. Stains, S. C. Meyer, I. Ghosh, J. Am. Chem. Soc. 2006, 128, 14456- 14457.

[125] T. N. M. Schumacher, L. M. Mayr, D. L. Minor, M. A. Milhollen, M. W. Burgess, P. S. Kim, Science 1996, 271, 1854-1857.

[126] S. M. Malakauskas, S. L. Mayo, Nat. Struct. Biol. 1998, 5, 470-475.

[127] R. Sabate, J. Estelrich, Langmuir 2005, 21, 6944-6949.

[128] A. I. Bush, Neurobiol. Aging 2002, 23, 1031-1038.

[129] H. A. Lashuel, D. M. Hartley, D. Balakhaneh, A. Aggarwal, S. Teichberg, D. J. E. Callaway, J. Biol. Chem. 2002, 277, 42881-42890.

[130] S. Taniguchi, N. Suzuki, M. Masuda, S. Hisanaga, T. Iwatsubo, M. Goedert, M. Hasegawa, J. Biol. Chem. 2004, 280, 7614- 7623.
[131] F. S. Yang, G. P. Lim, A. N. Begum, O. J. Ubeda, M. R. Simmons, S. S. Ambegaokar, P. P. Chen, R. Kayed, C. G. Glabe, S. A. Frautschy, G. M. Cole, J. Biol. Chem. 2004, 280, 5892-5901.

[132] S. J. Pollack, I. I. J. Sadler, S. R. Hawtin, V. J. Tailor, M. S. Shearman, Neurosci. Lett. 1995, 197, 211- 214.

[133] H. Bennhold, Dtsch. Arch. Klin. Med. 1923, 142, 32- 46.

[134] P. Divry, J. Neurol. Psychiatry 1927, 27, 643-657.

[135] G. Kelenyi, J. Histochem. Cytochem. 1967, 15, 172- 180.

[136] P. S. Vassar, C. F. A. Culling, Arch. Pathol. 1959, 68, 487- 498.

[137] R. Khurana, V. N. Uversky, L. Nielsen, A. L. Fink, J. Biol. Chem. 2001, 276, 22715- 22721.

[138] A. Lorenzo, B. A. Yankner, Proc. Natl. Acad. Sci. USA 1994, 91, $12243-12247$.

[139] L. S. Cai, F. T. Chin, V. W. Pike, H. Toyama, J. S. Liow, S. S. Zoghbi, K. Modell, E. Briard, H. U. Shetty, K. Sinclair, S. Donohue, D. Tipre, M. P. Kung, C. Dagostin, D. A. Widdowson, M. Green, W. Gao, M. M. Herman, M. Ichise, R. B. Innis, J. Med. Chem. 2004, 47, 2208-2218.

[140] V. M. Y. Lee, Neurobiol. Aging 2002, 23, 1039- 1042.

[141] H. LeVine, Biochemistry 2005, 44, 15937-15943.

[142] Y. Porat, A. Abramowitz, E. Gazit, Chem. Biol. Drug Des. 2006 $67,27-37$.

[143] B. J. Blanchard, A. Chen, L. M. Rozeboom, K. A. Stafford, P. Weigele, V. M. Ingram, Proc. Natl. Acad. Sci. USA 2004, 101, 14326-14332.

[144] D. M. Walsh, M. Townsend, M. B. Podlisny, G. M. Shankar, J. V. Fadeeva, O. El Agnaf, D. M. Hartley, D. J. Selkoe, J. Neurosci. 2005, 25, 2455- 2462.

[145] Y. Nakagami, S. Nishimura, T. Murasugi, T. Kubo, I. Kaneko, M. Meguro, S. Marumoto, H. Kogen, K. Koyama, T. Oda, Eur. J. Pharmacol. 2002, 457, 11- 17.

[146] A. Lockhart, L. Ye, D. B. Judd, A. T. Merritt, P. N. Lowe, J. L. Morgenstern, G. Z. Hong, A. D. Gee, J. Brown, J. Biol. Chem. 2004, 280, 7677-7684.

[147] L. Ye, J. L. Morgenstern, A. D. Gee, G. Z. Hong, J. Brown, A Lockhart, J. Biol. Chem. 2005, 280, 23599-23604.

[148] A. D. Ferrao-Gonzales, B. K. Robbs, V. H. Moreau, A. Ferreira, L. Juliano, A. P. Valente, F. C. L. Almeida, J. L. Silva, D. Foguel, J. Biol. Chem. 2005, 280, 34747-34754.

[149] M. Naoe, Y. Marumoto, R. Ishizaki, Y. Ogawa, Y. Nakagami, H. Yoshida, BJU Int. 2002, 90, 748-753.

[150] J. E. Gestwicki, G. R. Crabtree, I. A. Graef, Science 2004, 306 , 865-869.

[151] W. Kim, Y. Kim, J. Min, D. J. Kim, Y. T. Chang, M. H. Hecht, ACS Chem. Biol. 2006, 1, 461-469.

[152] G. S. Waldo, B. M. Standish, J. Berendzen, T. C. Terwilliger, Nat. Biotechnol. 1999, 17, 691-695.

[153] L. Crespo, G. Sanclimens, M. Pons, E. Giralt, M. Royo, F. Albericio, Chem. Rev. 2005, 105, 1663- 1681.

[154] M. Zhou, D. Bentley, I. Ghosh, J. Am. Chem. Soc. 2004, 126, 734-735.

[155] W. E. Klunk, H. Engler, A. Nordberg, Y. M. Wang, G. Blomqvist, D. P. Holt, M. Bergstrom, I. Savitcheva, G. F. Huang, S. Estrada, B. Ausen, M. L. Debnath, J. Barletta, J. C. Price, J. Sandell, B. J. Lopresti, A. Wall, P. Koivisto, G. Antoni, C. A. Mathis, B. Langstrom, Ann. Neurol. 2004, 55, 306-319.

[156] C. A. Mathis, Y. Wang, W. E. Klunk, Curr. Pharm. Des. 2004, 10, 1469- 1492. 